\title{
Comparing three vegetation monoterpene emission models to measured gas concentrations with a model of meteorology, air chemistry and chemical transport
}

\author{
S. Smolander ${ }^{1,}$, Q. He ${ }^{1,2}$, D. Mogensen ${ }^{1,3}$, L. Zhou ${ }^{1}$, J. Bäck ${ }^{4}$, T. Ruuskanen ${ }^{1}$, S. Noe ${ }^{5}$ A. Guenther ${ }^{6}$ H. Aaltonen ${ }^{4}$, \\ M. Kulmala ${ }^{1}$, and M. Boy ${ }^{1}$ \\ ${ }^{1}$ Division of Atmospheric Sciences, Department of Physics, P.O. Box 48, University of Helsinki, 00014 Helsinki, Finland \\ ${ }^{2}$ Remote Sensing Laboratories, Department of Geography, University of Zurich, Zurich, Switzerland \\ ${ }^{3}$ Helsinki University Centre for Environment, P.O. Box 27, University of Helsinki, 00014 Helsinki, Finland \\ ${ }^{4}$ Department of Forest Sciences, P.O. Box 27, University of Helsinki, 00014 Helsinki, Finland \\ ${ }^{5}$ Department of Plant Physiology, Institute of Agricultural and Environmental Sciences, Estonian University of Life Sciences, \\ Tartu, Estonia \\ ${ }^{6}$ Pacific Northwest National Laboratory, Atmospheric Sciences and Global Change Division, Richland, WA 99352, USA \\ *now at: Finnish Meteorological Institute, P.O. Box 503, 00101 Helsinki, Finland
}

Correspondence to: S. Smolander (sampo.smolander@helsinki.fi)

Received: 6 September 2013 - Published in Biogeosciences Discuss.: 28 November 2013

Revised: 31 July 2014 - Accepted: 4 September 2014 - Published: 7 October 2014

\begin{abstract}
Biogenic volatile organic compounds (BVOCs) are essential in atmospheric chemistry because of their chemical reactions that produce and destroy tropospheric ozone, their effects on aerosol formation and growth, and their potential influence on global warming. As one of the important BVOC groups, monoterpenes have been a focus of scientific attention in atmospheric research. Detailed regional measurements and model estimates are needed to study emission potential and the monoterpene budget on a global scale. Since the use of empirical measurements for upscaling is limited by many physical and biological factors, such as genetic variation, temperature and light, water availability, seasonal changes, and environmental stresses, comprehensive inventories over larger areas are difficult to obtain. We applied the boundary-layer-chemistry-transport model SOSA (model to Simulate the concentrations of Organic vapours and Sulphuric Acid) to investigate Scots pine (Pinus sylvestris) monoterpene emissions in a boreal coniferous forest at the SMEAR (Station for Measuring forest Ecosystem-Atmosphere Relations) II site, southern Finland. SOSA was applied to simulate monoterpene emissions with three different emission modules: the semiempirical G95, MEGAN (Model of Emissions of Gases and Aerosols from
\end{abstract}

Nature) 2.04 with improved descriptions of temperature and light responses and including also carbonyl emissions, and a process-based model SIM-BIM (Seasonal Isoprenoid synthase Model - Biochemical Isoprenoid biosynthesis Model). For the first time, the emission models included seasonal and diurnal variations in both quantity and chemical species of emitted monoterpenes, based on parameterizations obtained from field measurements. Results indicate that modelling and observations agreed reasonably well and that the model can be used for investigating regional air chemistry questions related to monoterpenes. The predominant modelled monoterpene concentrations, $\alpha$-pinene and $\Delta^{3}$-carene, are consistent with observations.

\section{Introduction}

The boreal zone is the world's second-largest forested region, after tropical forests (Global Forest Resources Assessment, 2000). Boreal vegetation is dominated by evergreen coniferous trees that produce a significant amount of biogenic volatile organic compounds (BVOCs), mainly monoand sesquiterpenes (Hakola et al., 1998; Rinne et al., 2009). 
Once emitted from vegetation, BVOCs have potential impacts on global climate due to their effects on atmospheric chemistry, aerosol formation and carbon balance.

BVOCs react with $\mathrm{O}_{3}, \mathrm{OH}$ and $\mathrm{NO}_{3}$ radicals and transform to less volatile organic compounds that in turn condense as secondary organic aerosols (SOA) (Kulmala et al., 2004). They are also crucial for stabilized Criegee radicals (Mauldin et al., 2012). Some of the oxidation products of BVOCs trigger new aerosol particle formation (e.g. Boy et al., 2003; Kanakidou et al., 2005; Kulmala et al., 2013). This affects the optical properties of aerosols (Noziére and Esteve, 2005) and causal feedback mechanisms to the Earth's radiation (Fuentes and Wang, 1999). The oxidation of BVOCs results in the acidity of precipitation (Kawamura and Usukura, 1993), and the generated carbonyls photolyse and produce free radicals that interact during smog cycles (Tsigaridis and Kanakidou, 2002). Global volatile organic compound (VOC) emissions from biogenic sources (BVOC) have been estimated to be ca. $1000 \mathrm{Tg} \mathrm{yr}^{-1}$ (Guenther et al., 2012) and anthropogenic VOC (AVOC) ca. $110 \mathrm{Tg} \mathrm{yr}^{-1}$ (Piccot et al., 1992), $149 \mathrm{Tg} \mathrm{yr}^{-1}$ (Müller et al., 1992) or $130 \mathrm{Tg} \mathrm{yr}^{-1}$ (Lamarque et al., 2010).

As biogenic sources dominate the atmospheric VOC budget, especially in boreal regions, it is important to understand the dynamics of biogenic emissions and their consequences to atmospheric processes. Ecosystem BVOC emissions vary depending on biological (e.g. plant species, plant-specific emission capacity, phenology, biotic and abiotic stresses) and physical factors (e.g. temperature, light and water availability, $\mathrm{CO}_{2}$ concentration; e.g. Peñuelas and Staudt, 2010). Many BVOCs are important for plants as defensive compounds, e.g. in preventing the colonization of pathogens after wounding, in deterring insects or in recruiting the natural enemies of herbivores (Visser, 1986; Dicke et al., 1990; Kesselmeier and Staudt, 1999; Tooker et al., 2005).

It is not possible to directly compare modelled BVOC emissions to measured BVOC concentrations in or above the canopy since these chemicals undergo reactions and mixing in the atmosphere. In this study we include three different emission models in the boundary-layer-atmosphericchemistry-transport model SOSA (model to Simulate the concentrations of Organic vapours and Sulphuric Acid; Boy et al., 2011) and thus simulate the BVOC concentrations at different heights, allowing both chemical reactions and meteorological mixing to have their effect. Model results are compared to observed diurnal and annual in- and above-canopy monoterpene concentrations measured by proton-transferreaction mass spectrometry (PTR-MS). We also analyse the implications for the modelled atmospheric reactivity and monoterpene concentrations when we include i) variations in emission spectrum and ii) emissions from soil. The measurements were conducted at the SMEAR (Station for Measuring forest Ecosystem-Atmosphere Relations) II station, Hyytiälä, southern Finland (Hari and Kulmala, 2005). Since previous research shows that many of the tree species in the European boreal zone are monoterpene emitters (Janson, 1993; Hakola et al., 1998; Hauff et al., 1999), this paper will focus on monoterpene emissions.

\section{Models of vegetation BVOC emissions}

We used three different emission modules for estimating the robustness of atmospheric chemistry and gas concentrations modelled by SOSA: G95 (Guenther et al., 1995), MEGAN 2.04 (Model of Emissions of Gases and Aerosols from Nature; Guenther et al., 2006) and SIM-BIM (Seasonal Isoprenoid synthase Model - Biochemical Isoprenoid biosynthesis Model; Grote et al., 2006). The emission models coupled with SOSA provide on-line estimates of the landscapeaveraged emission rates of monoterpenes and other BVOCs from terrestrial ecosystems into the atmosphere at a specific location and time.

In addition to vegetation emissions, the soil can also release BVOCs into the air. We do not attempt to construct a process-based model for the soil emissions, but in order to not neglect the soil emissions, we feed data from continuous chamber measurements of soil surface BVOC emissions (see Sect. 4.3) into the atmosphere model (see Sect. 3).

\section{$2.1 \quad$ G95}

The emissions of organic vapours from the canopy were calculated as

emission $=\varepsilon \cdot \gamma \cdot \rho$,

where $\varepsilon\left(\mu \mathrm{g} \mathrm{m}^{-2} \mathrm{~h}^{-1}\right)$ is an ecosystem-dependent emission factor representing the emission of a compound into the canopy at a photosynthetically active radiation (PAR) flux of $1000 \mu \mathrm{mol} \mathrm{m}{ }^{-2} \mathrm{~s}^{-1}$ and a leaf temperature of $303.15 \mathrm{~K}$, referred to as standard emission potential. We assumed Scots pine to be the main tree species in our boreal forest ecosystem, and the seasonal standard monoterpene emission potentials used in the model were as given by Tarvainen et al. (2005) and Hakola et al. (2006). $\gamma$ (normalized ratio) is a nondimensional adjustment emission factor accounting for emission changes due to deviations from standard conditions, and $\rho$ (normalized ratio) is a factor accounting for production and loss within plant canopies.

The surface emission flux from the vegetation, $F_{\text {vegetation, }}$ was calculated in the model as (Guenther et al., 1995)

$F_{\text {vegetation }}=D_{m} \cdot \varepsilon \cdot \gamma$,

where $D_{m}\left(\mathrm{~kg}\right.$ dry matter $\left.\mathrm{m}^{-2}\right)$ is the foliar density of the pine stand, obtained from the leaf area index (LAI) with $0.538 \mathrm{~kg} \mathrm{~m}^{-2}$ adopted as the constant value at SMEAR II (Ilvesniemi et al., 2009). $\varepsilon$ ( $\mu \mathrm{g} \mathrm{m}^{-2} \mathrm{~h}^{-1}$ ) and $\gamma$ are the same as above. 


\subsection{MEGAN 2.04}

The improvements in MEGAN 2.04 (Guenther et al., 2006) relative to G95 are that individual VOC species are included in the model and driving variables such as temperature and light in the past days are also accounted for when calculating emissions. Emissions of methanol, formaldehyde, acetone and sesquiterpenes, which may contribute significantly to atmospheric concentrations of VOCs, were estimated by MEGAN 2.04 but are not part of this study because our third emission module (SIM-BIM, Sect. 2.3) only provides emission rates for monoterpenes. The emission activity factor $\gamma$ in MEGAN 2.04 is improved, and it accounts for the effects of soil moisture, leaf age and the canopy environment as

$\gamma=\gamma_{\mathrm{age}} \cdot \gamma_{\mathrm{SM}} \cdot \gamma_{\mathrm{CE}}$

where $\gamma_{\text {age }}$ makes adjustments for the effects of leaf age. It is calculated with an algorithm that assigns different emission activities to new, growing, mature and old leaves. $\gamma_{\mathrm{SM}}$ accounts for direct changes in $\gamma$ due to changes in soil moisture. $\gamma_{\mathrm{CE}}$ describes variation due to LAI and light, temperature, humidity and wind conditions within the canopy environment and is estimated as

$\gamma_{\mathrm{CE}}=C_{\mathrm{CE}} \cdot \gamma_{\mathrm{PT}} \cdot \mathrm{LAI}$,

where $C_{\mathrm{CE}}$ is a factor that sets the emission activity to unity at standard conditions, $\gamma_{\mathrm{PT}}$ is the weighted average of the product of a temperature emission activity factor $\left(\gamma_{\mathrm{T}}\right)$ and a photosynthetic photon flux density (PPFD) emission activity factor $\left(\gamma_{\mathrm{P}}\right)$, and LAI is the leaf area index. MEGAN $2.04 \mathrm{ex}-$ tends algorithms for estimating $\gamma_{\mathrm{T}}$ and $\gamma_{\mathrm{P}}$ instead of using the constant values recommended by Guenther et al. (1999), which improves the simulated variations in emission associated with past temperature and PPFD conditions (Guenther et al., 2006). Previous studies show that measured terpenoid standard emission potentials are higher when warm sunny conditions have occurred during the previous days and are lower if there were cool shady conditions (Sharkey et al., 2000). The impact on vegetation emissions by exposure to different temperatures and light levels could last for several weeks (Pétron et al., 2001). The factors controlling these variations may operate over a continuous range of timescales, but, for modelling purposes, MEGAN 2.04 considers only $24 \mathrm{~h}$ and $240 \mathrm{~h}$ (Guenther et al., 2006).

MEGAN 2.04 uses canopy-scale emission factors, while most other biogenic emission models use leaf-scale emission factors. Although canopy-scale measurements are becoming more available, the MEGAN 2.04 canopy-scale emission factors for temperate and boreal forests are still primarily based on leaf- and branch-scale emission measurements that are extrapolated to the canopy scale using a canopy environment model (Guenther et al., 2006).

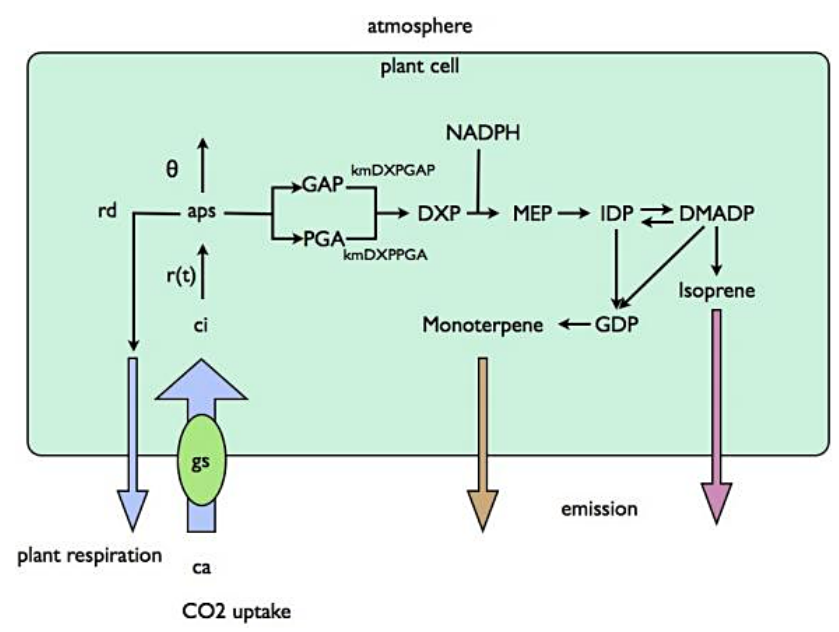

Figure 1. Reaction pathways of the SIM-BIM emission model. Here, $C_{\mathrm{a}}$ is $\mathrm{CO}_{2}$ concentration in the air; $C_{\mathrm{i}}$ is intercellular $\mathrm{CO}_{2}$ concentration; $g_{\mathrm{s}}$ is stomatal conductance; $A_{\mathrm{ps}}$ is assimilated carbon pool; $r(t)$ is photosynthesis rate as a function of light; $r_{\mathrm{d}}$ is dark respiration rate; $\theta$ is the fraction of carbon used in a plant's metabolism; kmDXPGAP and kmDXPPGA are Michaelis-Menten reaction coefficients; GAP is glyceraldehyde-3-phosphate; PGA is 3-phosphoglyceric aldehyde; DXP is 1-deoxy-D-xylulose 5phosphate; MEP is 2-C-methyl-D-erythritol 4-phosphate; NADPH is nicotinamide adenine dinucleotide phosphate; IDP is isopentenyl diphosphate; DMADP is dimethylallyl diphosphate; GDP is geranyl diphosphate.

\subsection{SIM-BIM}

A process-based model SIM-BIM was also used as an emission module. SIM-BIM takes into account the physiologi$\mathrm{cal} /$ phenological state of the leaves and the biochemical processes, such as the available carbon and energy resources leading to the formation of volatile isoprenoids (Grote et al., 2006). SIM-BIM is a combination of the seasonal isoprenoid synthase model SIM (Lehning et al., 2001), which dynamically describes the seasonal development of isoprenoid synthase, daily-step enzyme activity and the biochemical isoprenoid emission model BIM (Zimmer et al., 2000), which mechanically simulates volatile isoprenoid production in relation to environmental conditions.

SIM-BIM calculates changes in the concentrations of a number of isoprene and monoterpene precursors within the chloroplast (Grote, 2007). It basically consists of a sequence of first-order Michaelis-Menten enzymatic reactions that depend on instantaneous temperature (Grote et al., 2010). Figure 1 presents an overview of the metabolic pathways in SIM-BIM, and Appendix A contains the corresponding equations, parameter values and abbreviations used for the chemicals and other variables. Primary substrates for the emission model are provided by photosynthesis. The $C_{\mathrm{i}} / C_{\mathrm{a}}$ ratio is a sensitive indicator of stomatal conductance $\left(g_{\mathrm{s}}\right)$, which is very important for water use efficiency in 
photosynthesis. The basic carbon input is controlled by light intensity, humidity and temperature; the function $r(t)$ is controlled by light. Assimilated carbon $\left(A_{\mathrm{ps}}\right)$ is divided into three uses: the use of carbon in respiration (loss to atmosphere), the use of the carbon in the plant's metabolism $(\theta)$ and the use for isoprenoid production. GAP (glyceraldehyde3-phosphate) and PGA (3-phosphoglyceric aldehyde) are made of 3 carbon atoms, so $A_{\mathrm{ps}}$ used for isoprenoid production is divided by 3 to achieve one of these molecules. There is a fraction in the model that decides how much of GAP and PGA are built up and how much is transformed into DXP (1-deoxy-D-xylulose 5-phosphate) under different reaction rates $\left(K_{\mathrm{m}, \mathrm{DXP}, \mathrm{GAP}}\right.$ and $\left.K_{\mathrm{m}, \mathrm{DXP}, \mathrm{PGA}}\right)$. DXP then produces MEP (2-C-methyl-D-erythritol 4-phosphate) with the presence of NADPH (nicotinamide adenine dinucleotide phosphate), which is considered a constant in the model. MEP reacts further to IDP (isopentenyl diphosphate). IDP and DMADP (dimethylallyl diphosphate) are both five carbon atoms, are in equilibrium and have a certain equilibrium constant. When IDP and DMADP come together to form the 10-carbon monoterpene backbone molecule GDP (geranyl diphosphate), a monoterpene is emitted. The potential production rates are determined by activities of isoprenoid biosynthesis-related enzymes (Grote et al., 2010).

The formulation of the SIM-BIM emission model used here follows the original isoprene emission model by Zimmer et al. (2000), with monoterpene emissions as added by Grote et al. (2006) linked to a photosynthesis model by Noe and Giersch (2004). However, the model variables and parameters were scaled to be applicable at the level of the gas exchange surfaces of trees. This includes some modifications to the model. All pools are rates per area and not concentrations as is typical for enzymatic reaction systems. Due to a lack of validation data for conifers with several actively emitting needle ages, the seasonal changes modulating the reaction velocities in the seasonality module (Lehning et al., 2001; parameterized for deciduous oak trees) have not been applied. Instead, we parameterized the model equations with shoot chamber measurements data from the year 2007. Sets of 2 continuous days were chosen for each season (spring, summer, autumn and winter) of the 2007 data. We defined a distance function, and the minimization criteria was to minimize the root mean square difference between the model and measured data. Each parameter was allowed to change within a certain interval, and for each set of picked data, 30000 random choices of the parameters where realised using a normal distribution and tested against the criteria. Parameter combinations that successfully minimized the criterion were then chosen.

The model equations and parameter values of SIM-BIM as used in this study are presented in Appendix A.

\subsection{Chemotype effect on emissions}

Recent research carried out, e.g., at the field station SMEAR II (Bäck et al., 2012) has demonstrated that the Scots pine individuals differ in their chemotypes, i.e. the inherited capability of the tree individual to emit monoterpenes of a specific blend. Emissions can be dominated by either pinenes (both $\alpha$-pinene and $\beta$-pinene) or $\Delta^{3}$-carene, or a tree can have an intermediate chemotype and emit both in almost equal quantities. Table 1 shows the different monoterpene emission distributions from 40 sampled trees at the SMEAR II stand (data from Bäck et al., 2012). SOSA (see below) was employed to test the effects of chemodiversity on modelled monoterpene concentrations, $\mathrm{OH}$ reactivity and $\mathrm{OH}$ concentrations. Chemotype distribution according to Table 1 was set up in the model, so for different model runs we assumed all the trees were either of pinene type, carene type, intermediate type, or of a type described by the average of the population.

\section{Meteorology and chemistry models}

SOSA (Boy et al., 2011; Mogensen et al., 2011) is a onedimensional boundary layer and chemistry transport model. SOSA predicts wind, temperature, humidity, turbulence kinetic energy, dissipation and turbulent eddy diffusivity, and the corresponding fluxes for each height level. We used 51 height levels in the model, with increasing thickness for the higher levels. The levels start from ca. $20 \mathrm{~cm}$ thickness near the ground, have a thickness of ca. $3 \mathrm{~m}$ above the canopy (18 levels inside the canopy), and have a thickness of up to $250 \mathrm{~m}$ at the model top at $3 \mathrm{~km}$ height. The following inputs were used for running SOSA: vertical leaf area density and physiological canopy parameters for the SMEAR II site. Meteorological data from nearby meteorological observations (Jokioinen and Tikkakoski sounding stations) were used as model top (3000 m height) boundary conditions. Continuously measured meteorological data (temperature, humidity and wind speed at a height of 4, 8, 16, 33, 50 and $67 \mathrm{~m}$ ) from the SMEAR II mast were used for nudging the model variables towards the observations. The measured incoming solar radiation at SMEAR II was used for photochemistry, photosynthesis and energy balance.

The chemical kinetics module simulates the time evolution of the concentrations of the chemical species and reactions occurring at different levels in the atmosphere. The chemical reaction equations and the corresponding rate coefficients for the model were selected from the Master Chemical Mechanism (MCM version 3.1; http://mcm.leeds.ac.uk/MCM/). In total, 2140 reaction equations and 761 chemical species were used. These reactions represent the complete reaction paths for isoprene, $\beta$-pinene, $\alpha$-pinene, 2 -methyl-3-buten-2ol, methanol, methane, acetone, acetaldehyde, formaldehyde and all relevant inorganic reactions. As the MCM version 3.1 only included full chemistry pathways for the terpenes 
Table 1. Average proportions of monoterpenes from emission in the data set by Bäck et al. (2012) from three different tree chemotypes, and the average of the whole data set.

\begin{tabular}{lcccc}
\hline & $\begin{array}{c}\text { Pinene trees } \\
(n=15) \\
\text { mean }\end{array}$ & $\begin{array}{c}\text { Intermediate } \\
\text { trees }(n=17) \\
\text { mean }\end{array}$ & $\begin{array}{c}\Delta^{3} \text {-carene } \\
\text { trees }(n=8) \\
\text { mean }\end{array}$ & $\begin{array}{c}\text { Average of all } \\
\text { trees }(n=40) \\
\text { mean }\end{array}$ \\
\hline $\begin{array}{l}\alpha \text {-Pinene } \\
\Delta^{3} \text {-Carene }\end{array}$ & 0.601 & 0.420 & 0.169 & 0.437 \\
$\beta$-Pinene & 0.144 & 0.445 & 0.764 & 0.396 \\
Limonene & 0.171 & 0.053 & 0.018 & 0.090 \\
Camphene & 0.037 & 0.019 & 0.003 & 0.023 \\
Terpinolene & 0.003 & 0.022 & 0.008 & 0.018 \\
p-Cymene & 0.001 & 0.008 & 0.020 & 0.009 \\
1,8-Cineol & $<0.0005$ & 0.001 & 0.001 & 0.001 \\
\hline
\end{tabular}

$\alpha$-pinene and $\beta$-pinene, we adopted rate constants from Atkinson et al. (1994) for $\Delta^{3}$-carene, limonene, sabinene and camphene with $\mathrm{OH}, \mathrm{O}_{3}$ and $\mathrm{NO}_{3}$. For other monoterpenes we used the reaction rates of $\alpha$-pinene for the first reactions.

The Kinetic PreProcessor (KPP) (Damian, 2002; Sandu and Sanders, 2006) was used to translate the MCM reaction equations into Fortran code which performs the time integration of the kinetic system, and functions as a module to SOSA. The numerical solution of the system of these 761 differential equations and for each 51 height levels was the part that used the most computer resources. SOSA is written as a parallel program, and a simulation of, e.g., 1 month, with a $10 \mathrm{~s}$ time step in the model, took ca. 1 hour when run using 32 processor cores on a Linux cluster.

For a more detailed description of the model SOSA, we refer the reader to Boy et al. (2011) and Mogensen et al. (2011).

\section{Measurements}

\subsection{The SMEAR II site}

The study was carried out at the SMEAR II station $\left(61^{\circ} 51^{\prime} \mathrm{N}\right.$, $24^{\circ} 17^{\prime} \mathrm{E}, 180 \mathrm{~m}$ a.s.l.) located in the vicinity of the Hyytiälä Forestry Field Station in southern Finland. This is a unique field measurement station designed for continuous measurements of phenomena in which physical, chemical and biological processes interact (Hari and Kulmala, 2005). Vegetation at the station is dominated by 50 -year old Scots pine (>60\%), and the rest are Norway spruce (Picea abies (L) Karst.), European aspen (Populus tremula L.) and birch (Betula pendula Roth.) (Aaltonen et al., 2011). The average tree density is approximately 1370 stems (diameter-at-breast height $>5 \mathrm{~cm}$ ) per hectare, and the stand height is about $16 \mathrm{~m}$ with an open canopy (Ilvesniemi et al., 2009). Vascular plant species at ground level are mainly lingonberry (Vaccinium vitis-idaea L.), bilberry (Vaccinium myrtillus L.), wavy hair grass (Deschampsia flexuosa (L.) Trin.) and heather (Calluna vulgaris (L.) Hull.), while the most common mosses are Schreber's big stem moss (Pleurozium schreberi (Brid.) Mitt.) and a dicranum moss (Dicranum Hedw. sp.) (Ilvesniemi et al., 2009). The soil at the stand is mainly podzolic, characterized by a thin humus layer and low nitrogen level. The 30-year average annual precipitation at SMEAR II is $711 \mathrm{~mm}$, and the annual mean temperature is $3.5^{\circ} \mathrm{C}$ (Pirinen et al., 2012). More detailed information on the station can be found at http://www.atm.helsinki.fi/SMEAR or in Vesala et al. (1998) and Kulmala et al. (2001).

\subsection{VOC concentration and emission measurements}

VOC concentrations were measured with a PTR-MS (protontransfer-reaction mass spectrometer, Ionicon Analytik, Innsbruck, Austria). In the PTR-MS, compounds are ionized with a proton and detected at their protonated molecular mass $(\mathrm{M}+1)$, and thus all monoterpenes were detected as a sum at M137 (amu per charge). The monoterpenes were calibrated with an $\alpha$-pinene standard every second week, and background measurements of VOC free air were done every second or third hour. The detection limit of monoterpenes was of the order of $50 \mathrm{pptv}$ for two second measurements and of the order of $10 \mathrm{pptv}$ for the $1 \mathrm{~h}$ averages used in this study (Taipale et al., 2008). The uncertainty of the measurements is influenced by the monoterpene composition (changes in fragmentation efficiency), background signal (instrumental noise), integration time of sample and ambient conditions such as air humidity. The calibration gas mixture alone has an uncertainty of $5 \%$, and the total uncertainty is several times higher. Tani et al. (2003) determined that uncertainties of monoterpene concentration, influence of fragmentation and relative humidity are monoterpene specific; under normal operating conditions, the PTR-MS and GC-FID (Gas Chromatography-Flame Ionization Detector) measurement difference was $20 \%$. The sampling, calibration and concentration calculation protocol is described in detail by Taipale et al. (2008). Monoterpene concentrations were measured from continuous sampling flows from above the canopy ( $22 \mathrm{~m}$ height), the top part of the canopy $(16 \mathrm{~m})$ and 
from the below-canopy space $(4 \mathrm{~m})$. Fluxes of monoterpenes were determined with the disjunct eddy covariance method from measurements at $22 \mathrm{~m}$ height and are described in detail by Taipale et al. (2010).

\subsection{Forest floor emissions}

VOC emissions from soil and ground vegetation were measured between January and June 2009 using three flowthrough chamber. The chambers $(80 \times 40 \times 25 \mathrm{~cm})$, coated with a transparent fluorinated ethylene propylene film, were mounted on the permanently installed collars. The operation of the chambers was automatic; each chamber was closed pneumatically for $15 \mathrm{~min}$ once every $3 \mathrm{~h}$, i.e. 8 times per day, and the first $7 \mathrm{~min}$ non-steady-state part of the closure was used for quantifying the fluxes. Sample air was drawn from the chambers at a rate of $1.1 \mathrm{dm}^{3} \mathrm{~min}^{-1}$, and a smaller air sample (flow $0.1 \mathrm{dm}^{3} \mathrm{~min}^{-1}$ ) was diverted into PTR-MS with polytetrafluoroethylene tubing. To replace the sampled air volume in the chamber, compressed ambient air was supplied to the chamber at the same flow rate as the sample air was drawn out . VOC fluxes were calculated by fitting the mass balance equation to the development of measured VOC concentrations during chamber closure. The measurement setup and flux calculations are described in detail by Aaltonen et al. (2013).

The measured calibrated emission of protonated mass 137 with PTR-MS was read into the SOSA model in order to test its effect on the ambient monoterpene concentration from forest floor monoterpene emissions. An average of the data from the three cuvettes was taken, since these showed different fluxes, which is mostly due to the heterogeneity of soil and vegetation inside the cuvettes. The total monoterpene flux signal was divided into individual monoterpenes according to the average chemotype tree distribution given by Bäck et al. (2012) (as also seen in Table 1), since previous studies indicated that surface needle litter (Steinbrecher et al., 1999, Aaltonen et al., 2011, Hayward et al., 2001) contributes to the forest floor monoterpene emissions. We then linearly interpolated the measured flux of monoterpenes from the soil to fit our model time step and multiplied it with the height of our lowest layer $(=17 \mathrm{~cm})$ and our chemistry module time step and added this concentration to the already existing monoterpene concentration in the lowest model layer. Due to mixing, the soil-emitted monoterpenes will then disperse to higher vertical levels. If the measured flux was negative (due to measurement uncertainties and potentially also deposition to humid surfaces), we set the soil emission to 0 .

\section{Results and discussion}

In this section we validate the performance of the model with different chemotypic pine trees at SMEAR II and then compare the simulated results of monoterpenes with available

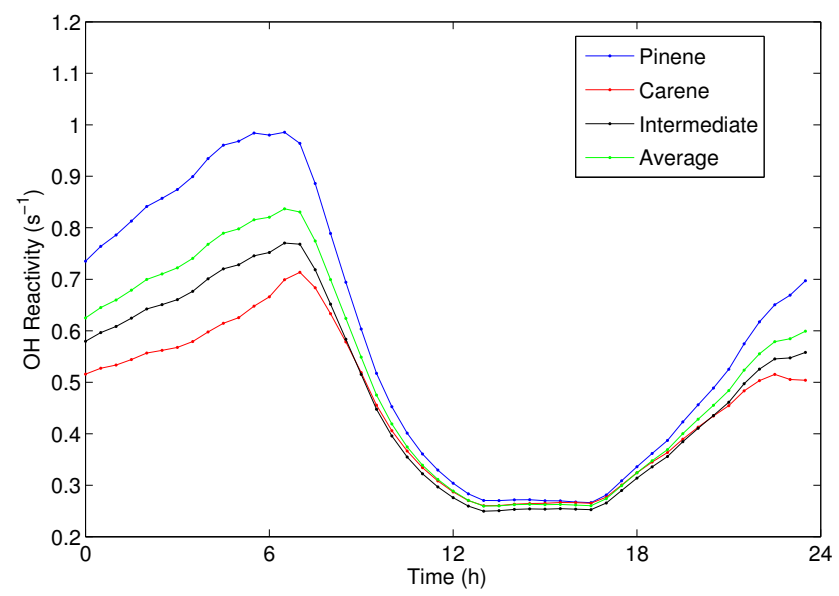

Figure 2. Average modelled (MEGAN 2.04) diurnal profiles of $\mathrm{OH}$ reactivity at $14 \mathrm{~m}$ for the summer of the year 2007 for the four chemotype scenarios (see Table 1 and Fig. 2).

measurements. Further, the seasonal, diurnal and vertical distributions of monoterpene concentrations are analysed, and the model uncertainties are discussed at the end.

\subsection{Tree chemotype effects on canopy air chemistry}

Table 2 shows the monthly mean concentrations for the sum of monoterpenes at $14 \mathrm{~m}$ height for three chemotype scenarios and for the scenario of average chemotypes, when run with the MEGAN 2.04 emission model. As expected, relatively large differences in the total monoterpene concentrations in the air are found between pinene-type and carene-type stands. This can be explained by the atmospheric chemistry of these compounds. Monoterpenes mainly react with the hydroxyl radical $(\mathrm{OH})$ during daytime and the nitrate radical $\left(\mathrm{NO}_{3}\right)$ during nighttime. However, $\Delta^{3}$-carene has higher reaction rates with both of these radicals $\left(88 \times 10^{-12} \mathrm{~cm}^{3}\right.$ molecule ${ }^{-1} \mathrm{~s}^{-1}$ and $9.1 \times 10^{-12} \mathrm{~cm}^{3}$ molecule $\left.\mathrm{s}^{-1}\right)$ than $\alpha$ pinene $\quad\left(53.7 \times 10^{-12} \mathrm{~cm}^{3}\right.$ molecule ${ }^{-1} \mathrm{~s}^{-1}$ and $6.16 \times 10^{-12} \mathrm{~cm}^{3}$ molecule ${ }^{-1} \mathrm{~s}^{-1}$ ) (Hakola, 2002). Therefore, more of $\alpha$-pinene emitted from different levels of the canopy can be transported to the $14 \mathrm{~m}$ measurement height before it undergoes reactions. Since the ozone concentrations at SMEAR II are small and monoterpene reaction rates with ozone are rather low, the impact from ozone is minor. The intermediate emission chemotype results are between the two other groups and quite similar to the average scenario.

The hydroxyl radical is the most important oxidant in the troposphere. Understanding of its sources and sinks is crucial when evaluating the oxidation capacity of the atmosphere. $\mathrm{OH}$ reactivity is defined as the total loss rate of $\mathrm{OH}$ radicals from the atmosphere and calculated by the sum of the concentration of the reactants in $\mathrm{OH}$ reactions multiplied by the specific reaction rates (similar to the way in which it was 
Table 2. Modelled (MEGAN 2.04) monthly mean monoterpene concentrations at $14 \mathrm{~m}$ for the year 2007 for four different scenarios assuming that the pine trees are of either (i) pinene, (ii) carene, (iii) intermediate chemotype or (iv) average of all three types. For the scenarios, see Table 1. (Numbers in $10^{9}$ molecules $\mathrm{cm}^{-3}$ ).

\begin{tabular}{lllllllllllll}
\hline Scenario & Jan & Feb & Mar & Apr & May & Jun & Jul & Aug & Sep & Oct & Nov & Dec \\
\hline Pinene & 1.60 & 1.01 & 2.87 & 1.52 & 3.37 & 8.30 & 11.0 & 4.76 & 1.50 & 3.22 & 1.38 & 1.45 \\
Carene & 0.73 & 0.54 & 1.66 & 0.91 & 1.99 & 5.69 & 7.11 & 3.20 & 0.79 & 1.47 & 0.61 & 0.61 \\
Intermediate & 1.08 & 0.72 & 2.11 & 1.15 & 2.53 & 6.59 & 8.59 & 3.76 & 1.08 & 2.18 & 0.92 & 0.95 \\
Average & 1.20 & 0.79 & 2.30 & 1.24 & 2.74 & 7.05 & 9.20 & 4.02 & 1.18 & 2.42 & 1.03 & 1.06 \\
\hline
\end{tabular}

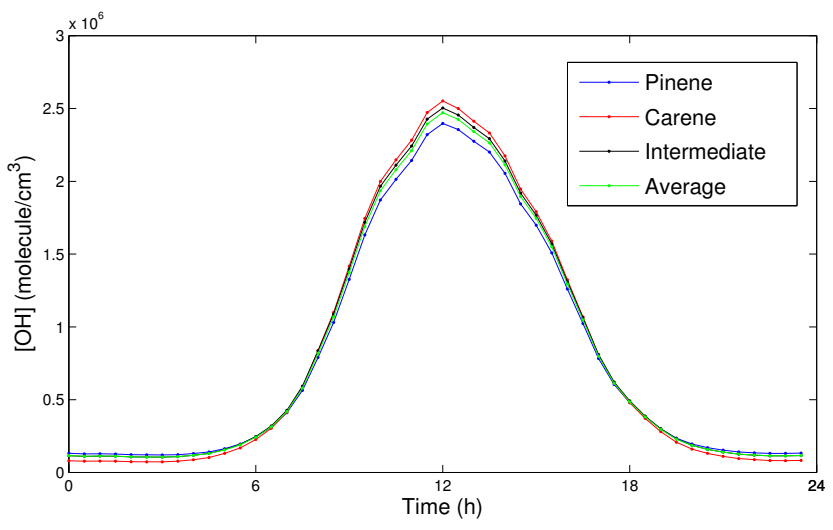

Figure 3. Average modelled (MEGAN 2.04) diurnal profiles of $\mathrm{OH}$ concentration at $14 \mathrm{~m}$ for the summer of the year 2007 for the four chemotype scenarios (see Tables 1 and 2).

calculated by Mogensen et al., 2011). The differences between modelled diurnal profiles of $\mathrm{OH}$ reactivity of the three chemotypes are clearest in the nighttime and in the early morning hours, with differences up to a factor of 1.5 between the pinene scenario and the carene scenario (Fig. 2). This is due to higher monoterpene concentrations remaining in the atmosphere in the pinene chemotype scenario than in the carene chemotype scenario after consumption by the nitrate radical. During daytime, relatively low monoterpene concentrations in the ambient air are available to react with the abundant $\mathrm{OH}$ radicals, so in the daytime the chemotype scenarios do not differ in $\mathrm{OH}$ reactivity.

The differences in diurnal profiles of $\mathrm{OH}$ concentrations between the chemotype scenarios are small (Fig. 3). Although the monoterpene concentrations in the pinene scenario are higher during daytime, they have lower reaction rates with $\mathrm{OH}$ radicals. These opposite effects result in an $\mathrm{OH}$ concentration in the pinene scenario that is only about $5 \%$ lower than in the carene scenario.

Since different monoterpenes have significantly different aerosol yields, they should have different potentials in new particle formation and growth. Ignoring tree chemodiversity may cause bias in related modelling results. The results from model simulations (Table 2, Figs. 2 and 3) demonstrate the

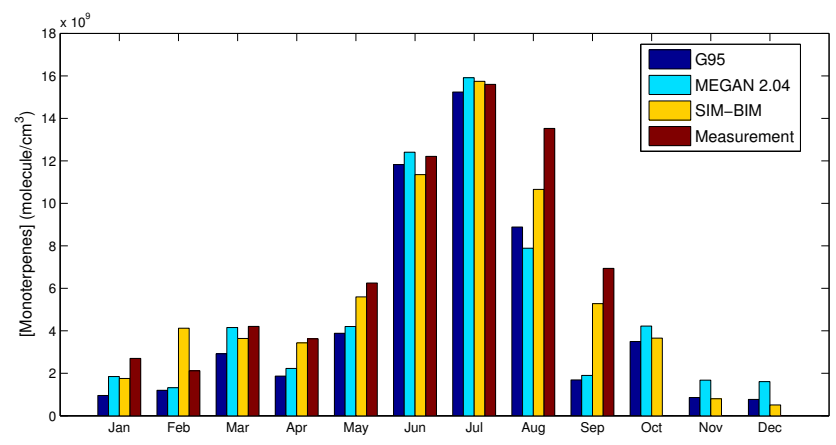

Figure 4. Comparison of modelled (G95, MEGAN 2.04, SIMBIM) and measured (at the SMEAR II station) average monthly monoterpene concentrations at $4 \mathrm{~m}$ height for the year 2007 .

magnitude of potential biases in air chemistry modelling if a model is based on only a single tree chemotype.

\subsection{Comparing different models with measurements}

For emission model intercomparison, we used the averaged chemotype scenario (see previous section). All models reproduce the annual pattern of monthly averages fairly well, especially during the highest concentrations in the summer (Fig. 4). In August-September, G95 and MEGAN 2.04 underestimate concentrations notably more than SIM-BIM, and in October-December all models overestimate the concentrations. The spring (April-May) high concentrations are best predicted by the SIM-BIM, whereas the MEGAN versions underestimate the concentrations by about $30 \%$.

In all three models, daytime emissions are around 2 times higher than those at night (Fig. 5), which corresponds to the reported daily pattern of emissions (e.g. Tarvainen et al., 2005). Otherwise all of the models agree quite well but in summer, SIM-BIM produces higher daytime emissions than G95 and MEGAN 2.04. Grote et al. (2006) considered that SIM-BIM might overestimate emissions during the hottest season, potentially due to lower enzyme activities during drought periods. The estimation of emission amounts has uncertainties related to measurements, model structure and model parameters (Grote et al., 2010).

Comparing hourly averages of modelled and measured monoterpene concentrations on a log-log scale in scatter 


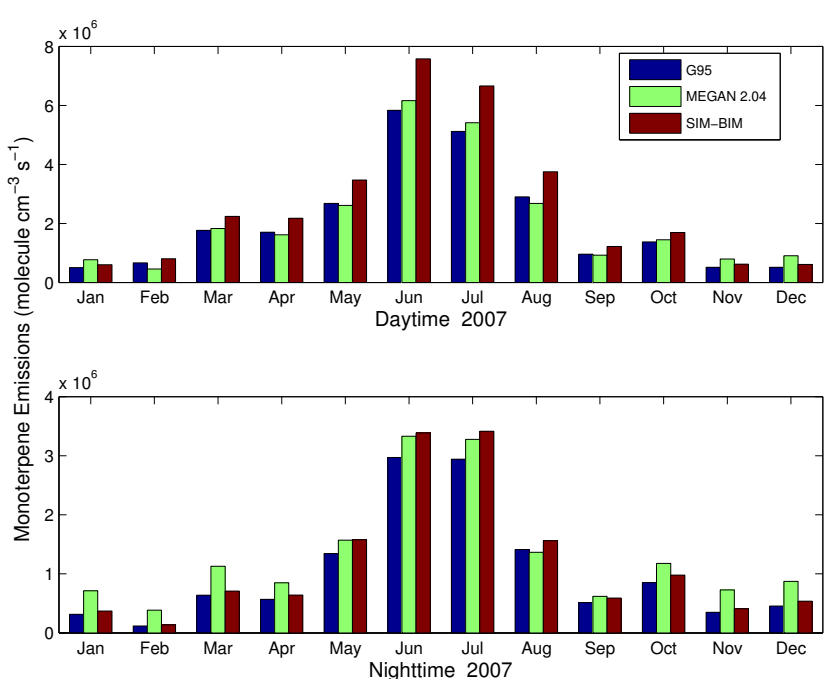

Figure 5. Modelled (G95, MEGAN 2.04, SIM-BIM) monthly averages of daytime and nighttime monoterpene emissions in the canopy at $14 \mathrm{~m}$ height.

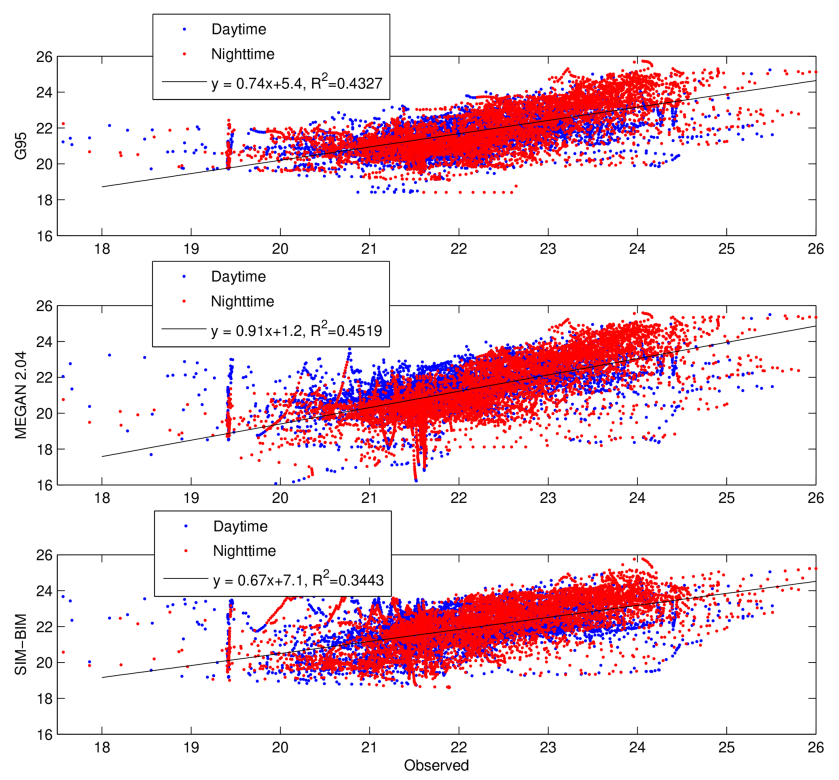

Figure 6. Scatter plots of modelled (G95, MEGAN 2.04, SIM$\mathrm{BIM})$ vs. measured hourly monoterpene concentrations on a $\log \left(\right.$ molecule $\left.\mathrm{cm}^{-3}\right)$ scale for the year 2007 data.

plots (Fig. 6), MEGAN 2.04 has a somewhat smaller bias and larger R2 (coefficient of determination) than the other two models. Therefore, we have chosen to proceed using MEGAN 2.04 and compare the model results with the measured concentrations and fluxes at the SMEAR II site (Figs. 7 and 8). The simulations yield a fairly good fit to measurements at both below and above canopy. The concentration minima appear at midday and the maxima at midnight, meaning that monoterpenes would be accumulated during the

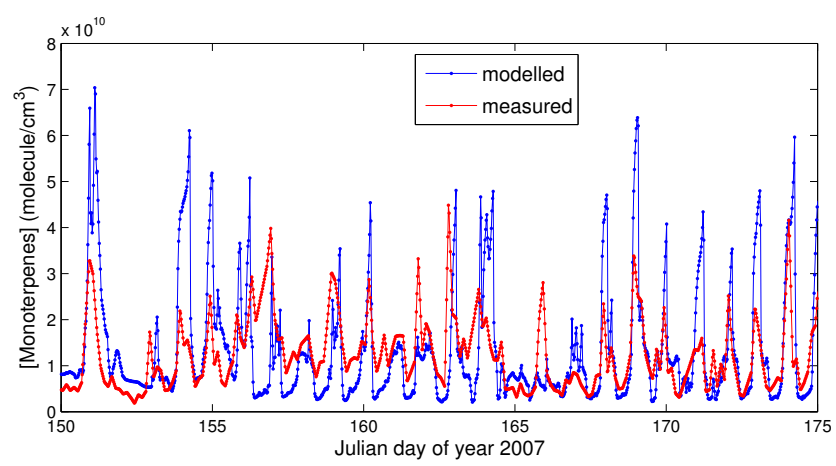

Figure 7. Modelled (MEGAN 2.04) and measured (at the SMEAR II station) monoterpene concentrations at $4 \mathrm{~m}$ height in June 2007.

night since emissions are not zero at night but continue in the absence of sunlight from the constitutive storage pools of needles and trunks (e.g. Schuh et al., 1997; Loreto et al., 2000; Niinemets et al., 2002b, Schurgers et al., 2009). Although the total emissions are much higher during daytime, increased turbulent mixing and chemical reactions with hydroxyl radicals consuming a large amount of monoterpenes result in the lowest concentrations during the day. The daytime contribution of the endogenous storage pools to monoterpene emissions from Scots pine can be about $40 \%$ (Ghirardo et al., 2010), whereas, at night, emissions from permanent storage make up most of the detected monoterpenes. The storage pool size in conifer tissues is dependent on the turnover rate of stored compounds, which is in turn a product of filling up the storage by de novo synthesis and a product of the temperature-dependent evaporation from storage (Shurgers et al., 2009). It is evident that the longterm storage dynamics are an important feature that should be implemented in models in future and that the emissions from storage may also influence concentrations of some compounds (Sallas et al., 2003; Ghirardo et al., 2010).

Meteorological data (not shown) show that the previous days were sunny and warm, but, then, days 165-167 were overcast and colder, with the exception of a warm evening on day 166. This is probably the reason for the drop in measured concentrations for days $165-167$ in Fig. 7, and it is the reason for the drop in modelled concentrations as the emission algorithm is driven primarily by sunlight and also by temperature. The warm (but still overcast) evening of day 166 is potentially the reason for the concentration peak in the night of day 166, but as the emission model is primarily driven by sunlight, the model does not react to change in only temperature, and there is no peak in modelled concentration. Following this, half of day 167 was sunny, and this could explain the peak in the modelled concentration, but the whole day remained cold, which could explain the absence of a peak in the measurements. The following days then got warmer and sunnier again. 


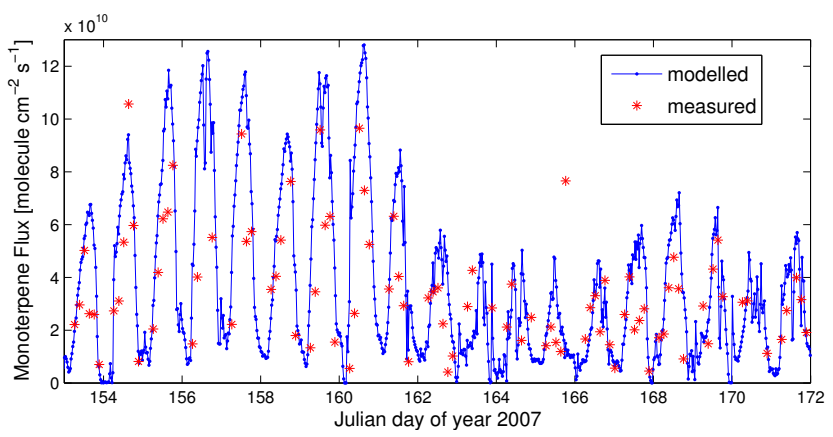

Figure 8. Modelled (MEGAN 2.04) and measured (at the SMEAR II station) monoterpene flux at $22 \mathrm{~m}$ height in June 2007.

\subsection{Monoterpene emissions from forest floor}

Our understanding of processes related to monoterpene emissions from soil, ground vegetation and decomposing litter is still limited, but their role in ecosystem-scale emissions is not negligible. During high forest floor emission seasons, such as spring and autumn, the emissions from soil and ground vegetation can be ca. $10 \%$ of the total monoterpene emissions from the forest ecosystem at SMEAR II (Aaltonen et al., 2011; 2013). Previous studies have indicated that both surface needle litter (Steinbrecher et al., 1999), soil microorganisms (Bäck et al., 2010) and roots (Janson, 1993) contribute to monoterpene emissions (Hayward et al., 2001). Greenberg et al. (2012) used enclosure and micrometeorological techniques to quantify a small $(<1 \%)$ contribution of litter and roots to the ecosystem-scale monoterpene flux in a temperate pine forest. The variation of emissions from the forest floor throughout the year is suggested to originate from changes in litter quantity and quality, soil microbial activity and the physiological stages of plants (Aaltonen et al., 2011). In autumn, when the oldest age class of needles drops to the floor, the stored monoterpenes from the litter will be released during decomposition (Aaltonen et al., 2011), which makes the emissions even higher than during summer, although weather conditions in autumn are less favourable. Emissions from ground vegetation and soil can even be sustained throughout the year, as shown by high concentrations inside the snowpack (Aaltonen et al., 2012).

Measured forest floor emission of monoterpenes (Aaltonen et al., 2013) were read into the model in order to test the effect of forest floor processes on the ambient monoterpene concentrations. During winter (January and February), when the soil is cold and covered by snow, the soil flux is low and, therefore, the contribution to the total monoterpene flux is negligible, which is why we observe a very small increase in near-ground monoterpene concentration. An obvious increase (around $10 \%$ ) of monoterpene concentrations caused by soil emissions is visible especially in spring and late spring, when the soil is active (Fig. 9). However, especially in April, the model was not able to capture these dynam-

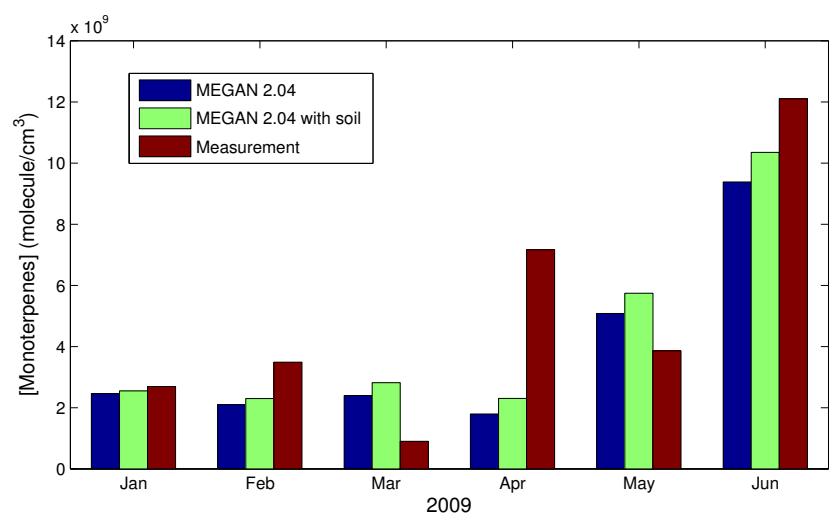

Figure 9. Modelled (MEGAN 2.04 without and with soil emissions) and measured (at the SMEAR II station) monoterpene concentrations at $4 \mathrm{~m}$ height in January-June 2009.

ics properly, and we observe a large underestimation compared with the measured concentration. Autumn is usually supposed to be the other peak season, but at this time, data were not available for autumn, and, therefore, the model was only run for springtime. The dynamic processes of monoterpene emissions from the forest floor are still poorly understood, and more field data are needed to explain the controlling mechanisms.

\subsection{Monoterpene composition at SMEAR II}

As different monoterpenes differ in their atmospheric lifetime and reactivity, it is important to identify the monoterpene composition in the ambient air. According to simulations (with MEGAN 2.04), the most abundant monoterpenes were $\alpha$-pinene and $\Delta^{3}$-carene (Fig. 10). This is compatible with the measured data as well as with many other studies (Rinne et al., 1999; Hakola et al., 2006; Tarvainen et al., 2007). $\beta$-pinene also contributes significantly to the total monoterpene concentration: $18 \%$ according to the model and $5 \%$ in observations. These three compounds represented over $90 \%$ of the total monoterpene concentration in both modelling and measurements.

Camphene, sabinene and limonene contributed, in decreasing order, to model results, with a proportion of $10 \%$ in total but much less in the measurements (except in the case of limonene, which contributed slightly more). The other species could be 1,8-cineole, ocimene or maybe some other monoterpenes with small concentrations but high reactivity in the atmosphere.

The composition distributions of modelling and observations were different in some ways: $\beta$-pinene and camphene were more abundant, whereas $\Delta^{3}$-carene was less abundant in the simulations compared with the measured values. The reason could be the chemistry of monoterpenes in the troposphere. As mentioned before, $\Delta^{3}$-carene $\left(9.1 \times 10^{-12} \mathrm{~cm}^{3}\right.$ molecule $\left.{ }^{-1} \mathrm{~s}^{-1}\right)$ has a much faster reaction 


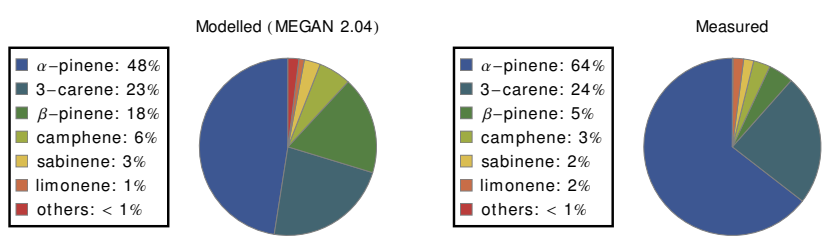

Figure 10. Modelled (MEGAN 2.04) and measured (Hakola et al., 2009) monoterpene composition at $14 \mathrm{~m}$ height at the SMEAR II station in summer 2007.

Table 3. Modelled (MEGAN 2.04) seasonal contributions of individual monoterpene proportions (in \% to total monoterpene concentrations) at $14 \mathrm{~m}$ height for each season of the year 2007.

\begin{tabular}{lllll}
\hline Monoterpenes (\%) & Spring & Summer & Autumn & Winter \\
\hline$\alpha$-Pinene & 48.76 & 47.16 & 51.99 & 49.59 \\
$\Delta^{3}$-Carene & 21.67 & 23.57 & 16.03 & 13.46 \\
$\beta$-Pinene & 18.85 & 17.45 & 20.76 & 22.14 \\
Camphene & 5.87 & 5.96 & 6.64 & 10.38 \\
Sabinene & 2.18 & 3.17 & 2.09 & 2.32 \\
Limonene & 1.18 & 1.07 & 1.37 & 1.31 \\
Others & 1.35 & 1.66 & 1.33 & 0.80 \\
\hline
\end{tabular}

rate when reacting with nitrate radicals at night than $\beta$ pinene $\left(2.51 \times 10^{-12} \mathrm{~cm}^{3}\right.$ molecule $\left.{ }^{-1} \mathrm{~s}^{-1}\right)$ and camphene $\left(6.6 \times 10^{-13} \mathrm{~cm}^{3}\right.$ molecule $\left.{ }^{-1} \mathrm{~s}^{-1}\right)$. In Fig. 10, the modelled composition was the average of both day and night monoterpene concentrations, but the measured concentration was the daytime distribution from the study by Hakola et al. (2009). In the nighttime, $\Delta^{3}$-carene was consumed to a large extent; however, $\beta$-pinene and camphene were accumulated. Therefore, $\Delta^{3}$-carene was $40 \%$ in the measured composition but dropped to $23 \%$ in the modelled one, while the ratios of $\beta$ pinene and camphene in the simulations doubled and tripled, respectively.

\subsection{Seasonal and diurnal variation in monoterpene concentrations}

According to many previous studies, the seasonal differences in monoterpene emissions cannot be reconciled solely with instantaneous meteorological data of light and temperature. Increasing evidence shows that a great part of seasonal variations in emissions results from long-term plant phenological responses, such as budding, flowering, fruiting, defencerelated metabolism, leaf senescence and dormancy (Robertson et al., 1995; Hakola et al., 1998; Niinemets et al., 2002a; Lappalainen et al., 2009; Monson et al., 2012). Growth conditions, such as past and current temperature, light intensity, nutrition status, and water availability, are linked to the variations as well (Sharkey and Loreto, 1993; Bertin and Staudt, 1996; Serca et al., 2001).

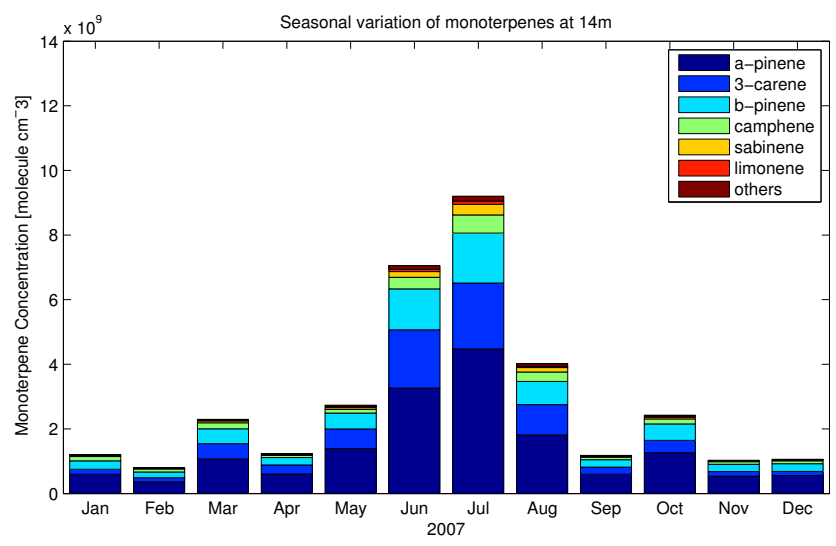

Figure 11. Modelled (MEGAN 2.04) distribution of individual monoterpene concentrations at $14 \mathrm{~m}$ height for the year 2007.

Table 3 summarizes the modelled relative contributions of individual monoterpenes to concentrations at the top of the canopy in different seasons. The spectrum is quite similar throughout the whole year, with the largest contributor being $\alpha$-pinene, followed by $\Delta^{3}$-carene and $\beta$-pinene. This is consistent with observations (Hakola et al., 2009) at the SMEAR II site, and also with findings from a Scots pine forest in southern Germany (Komenda and Koppmann, 2002). The three main compounds accounted for ca. $90 \%$ throughout the year. Almost $50 \%$ of monoterpenes was $\alpha$-pinene in all seasons, and $\Delta^{3}$-carene was slightly higher than $\beta$ pinene in spring and summer but lower in autumn and winter. Camphene, sabinene and limonene were minor constituents of the total monoterpene concentrations, and other uncertain monoterpenes accounted for about $1 \%$ of the total.

The concentrations reach the maximum in June-August due to strong biogenic emissions in summer (Fig. 11) (Hakola et al., 2006, 2009). A clear seasonal cycle is visible with higher concentrations in early spring and then a decrease in late spring. This type of seasonal behaviour was also described by Tarvainen et al. (2005), Hakola et al. (2006) and Lappalainen et al. (2009). Potential reasons for high springtime emissions are the storage pool dynamics, stresses during the spring recovery period and physiological factors related to the breaking of dormancy. Tarvainen et al. (2005) and Schurgers et al. (2009) have proposed that the storage pools of monoterpenes might be empty after winter and the new emissions first occur with light-dependent production (strong irradiance in connection with rather low temperature and low water availability in early spring).

\subsection{Vertical profiles of monoterpene concentrations}

The modelled and measured daily vertical distribution of monoterpene concentrations in summer and winter presented in Figs. 12 and 13 gives qualitative insights into monoterpene sources and sinks in this forest canopy. The higher concentrations inside the canopy at night demonstrate that 


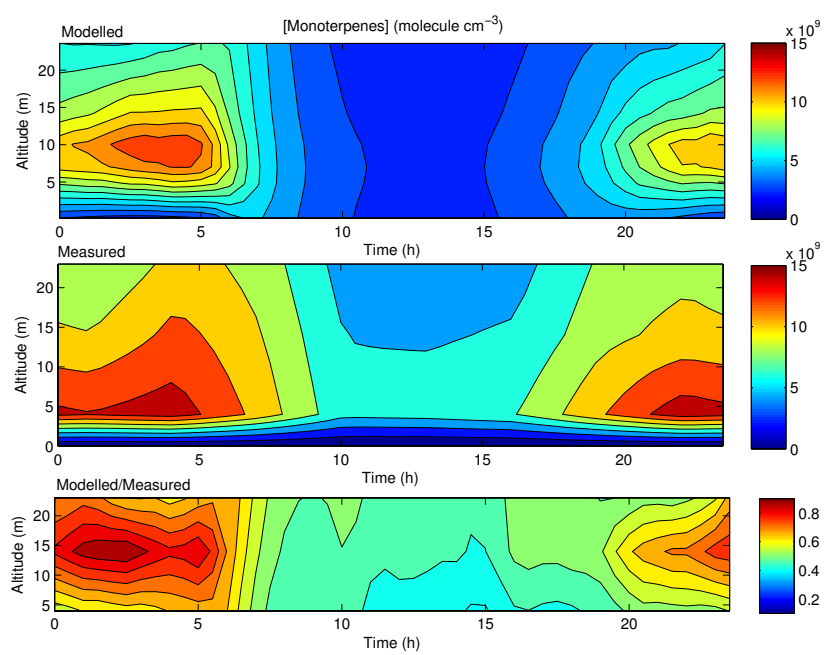

Figure 12. Modelled (MEGAN 2.04) and measured (at the SMEAR II station) monoterpene concentration vertical profiles for summer 2007.

emissions originate mainly from the forest canopy. Very low values, both in summer and in winter, were consistently always found near the ground. The concentrations at all heights were about 3-4 times higher in summer than in winter, indicating stronger emissions in summer. The daytime convective mixed layer concentrations are controlled by a balance between emissions from vegetation and reaction with $\mathrm{OH}$, the main daytime sink (Kuhn et al., 2002). Despite high emissions, turbulent mixing and reactions with $\mathrm{OH}$ reduced the concentrations. Turbulent mixing due to thermal convection as the day progresses made monoterpenes well mixed at all height levels in the atmospheric boundary layer during the day in summer, whereas the turbulence and mixing were slower during winter, which results in weaker transport of monoterpenes during winter daytime. High nighttime concentrations in the two figures are evident, indicating that monoterpene concentrations were quite stable at night without the influence of photochemistry and vertical mixing. High nighttime concentrations also support the theory of continuous monoterpene emissions at night from Scots pine storage pools.

The modelled vertical profile of monoterpene concentrations agreed reasonably well with the observations. The best correspondence is found near the canopy top during nighttime in both summer and winter. The contours in the modelled vertical profile are more detailed, since measurements of monoterpene concentrations were only conducted at three heights ( $4 \mathrm{~m}, 14 \mathrm{~m}, 22 \mathrm{~m}$ ). Observed monoterpene concentrations were of the same order of magnitude as the simulations both in summer and in winter and appeared in similar distribution patterns as described above. This demonstrates that SOSA is able to reproduce meaningful profiles, at least for the nighttime monoterpene concentrations.

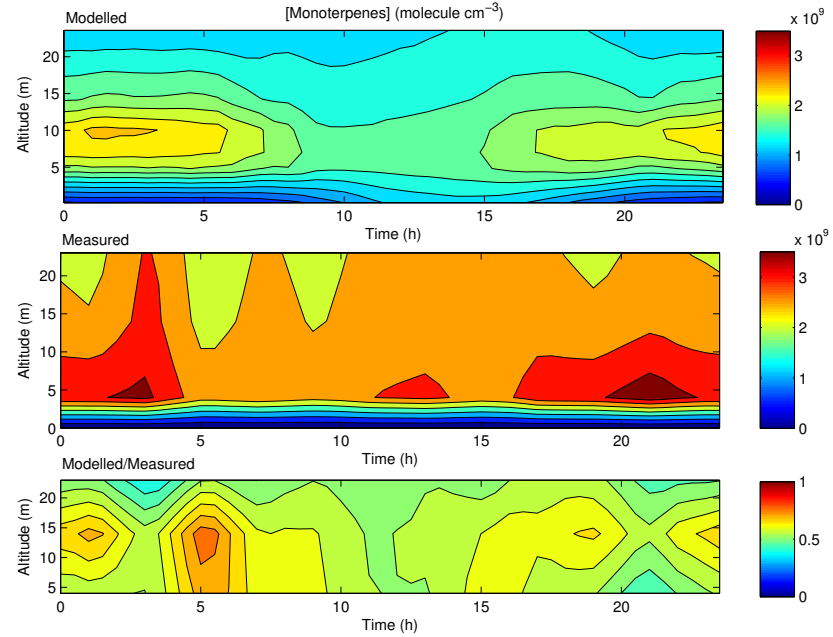

Figure 13. Modelled (MEGAN 2.04) and measured (at the SMEAR II station) monoterpene concentration vertical profiles for winter 2007.

\subsection{Model uncertainties}

Despite the progress in understanding biogenic emissions from vegetation, uncertainties in emission estimates are still large for several reasons (e.g. Arneth et al., 2008). Based on comparisons with the above canopy measurements, an uncertainty factor of 3 for monoterpene emissions has been reported in German regions where accurate model inputs are available (Smiatek and Steinbrecher, 2006). Stewart et al. (2003) reported an uncertainty factor of 4 for biogenic emissions in Great Britain and Simpson et al. (1999) an uncertainty factor of 3 to 5 for isoprene and monoterpene emissions from vegetation on a European scale. Specific to our research, the uncertainties in monoterpene estimates result from insufficient knowledge on the canopy-scale emission potentials and on the mechanisms controlling emissions, related to variations in plant physiological activity.

The Scots pine emission algorithms used in SOSA were only used for monoterpenes and thus do not represent isoprene emission at the SMEAR II stand. The stand is pine dominated, but some isoprene is emitted by co-occurring species, such as Norway spruce, European aspen and many willow species as well as the occasional silver birch and white birch. Further, the large, inherited chemotypic variations in the emission spectrum between individuals of the same tree species indicate the problems of obtaining emission parameters from too few individuals. The emission spectrum averaged from several tree individuals may be the best way to obtain robust emission parameters. 


\section{Conclusions}

The lack of sufficient understanding of temporal, spatial and qualitative variations in BVOC emissions has been hindering the development of atmospheric chemistry models. Although many different types of emission models exist, the connection between vegetation emissions and observed gas concentrations inside and above the canopy has rarely been tested.

We show here that three different monoterpene emission models (G95, MEGAN, SIM-BIM), together with the chemistry transport model SOSA, are able to model monoterpene concentrations in the air at different heights in the canopy with reasonable accuracy when compared to the measured concentrations in a boreal forest stand. Concentration measurements in the canopy air are point measurements and could be expected to be more difficult even for a good model to predict closely, and spatial heterogeneity (exact locations and chemotypes of nearby trees) can introduce local variance. Above-canopy flux measurements have a footprint (source area) and thus represent spatial averages. And, indeed, there was a larger discrepancy between modelled and measured concentrations in the canopy air (Fig. 7) than between the modelled and measured flux above the canopy (Fig. 8).

Regarding seasonal emission patterns (especially in the midsummer period), all three models agreed fairly well with the measurements, although their theoretical basis was quite different. Importantly, the modelled (MEGAN 2.04) monoterpene and $\mathrm{OH}$ concentrations seem to be very sensitive to variations in emission composition, which can lead to about $30 \%$ bias in atmospheric $\mathrm{OH}$ reactivity estimates.

There was some discrepancy in the modelled (MEGAN $2.04)$ and measured proportions of $\alpha$ - and $\beta$-pinene, but the proportion of $\Delta^{3}$-carene was modelled well (Fig. 10). Throughout the vertical profiles, the largest discrepancy between modelled (MEGAN 2.04) and measured gas concentrations occurs during the summer days (Figs. 7, 12, 13), and it is difficult to say whether this is related more to the way the emission model calculates emissions during the hours of ample sunlight and peak photosynthesis or to how the meteorology model calculates vertical mixing and the transport of the gases out of the canopy. (Due to the thermal structure of the atmospheric boundary layer, vertical mixing is also at its strongest during the summer daylight hours.)
As foliage is the only source for monoterpenes in all emission models, other sources within the stand are usually not accounted for. Implementing the ground vegetation and soil as sources for monoterpenes seems to be necessary since they may account for about $10 \%$ of the total stand emissions at times, and omitting these sources will lead to a significant underestimation of gas concentrations, especially in fall. However, more measurements and a process-based understanding of different sources within a coniferous stand are required.

The models used in this study calculate the BVOC emissions based on vegetation canopy (tree species, LAI, leaf age) and abiotic factors (sunlight, temperature, moisture). Insofar as BVOC emissions are scaled from leaf to canopy using a canopy-level model or light penetration, temperature, etc., the accuracy of the modelled canopy-level BVOC emissions are necessarily modulated by the accuracy of the canopy model in use. With regard to other aspects, there have been suggestions to include a factor related to phenological processes, modulating the modelled emissions (Staudt et al., 2000; Helmig et al., 2013). Also, other processes such as abiotic stresses (Loreto and Schnitzler, 2010; Niinemets, 2010) and herbivory (Trowbridge and Stoy, 2013) can be important in affecting BVOC emission levels (Loreto and Schnitzler, 2010; Niinemets, 2010). Assessing the importance of these processes for the needs of atmospheric chemistry models and the further modelling of these processes warrants further studies. Our approach, using a boundary layer meteorology model and chemical transport model to "connect" the vegetation emission models to measured chemical concentrations in the air, provides a framework for these further model comparisons. 
Appendix A: SIM-BIM emission model equations and parameters

Photosynthesis model equations:

$\frac{\mathrm{d}}{\mathrm{d} t} g_{\mathrm{s}}=k_{g}\left(G_{\max } \min \left(\frac{\alpha I}{\beta+I}, \min \left(1-\frac{\mathrm{VPD}}{\mathrm{VPD}_{0}}, 1\right)\right)-g_{\mathrm{s}}\right)$

$\frac{\mathrm{d}}{\mathrm{d} t} C_{\mathrm{i}}=g_{\mathrm{s}}\left(C_{\mathrm{a}}-C_{\mathrm{i}}\right)-\frac{\phi v_{I} I}{k_{I}+I} C_{\mathrm{i}}$

$\frac{\mathrm{d}}{\mathrm{d} t} A_{\mathrm{ps}}=\frac{\phi v_{I} I}{k_{I}+I} C_{\mathrm{i}}-\theta A_{\mathrm{ps}}-R_{d}$

BVOC emission model equations:

$$
\begin{aligned}
\frac{\mathrm{d}}{\mathrm{d} t} \mathrm{GAP} & =\frac{\left(1-f_{\mathrm{PGA}}\right)\left(A_{\mathrm{ps}} / 3+R_{d}\right)^{2}}{k_{\mathrm{MTP}}+A_{\mathrm{ps}} / 3+R_{d}} \\
& -V_{\mathrm{DXP}} \frac{\mathrm{GAP}}{K_{\mathrm{DXP}, \mathrm{GAP}}+\mathrm{GAP}} \frac{\mathrm{PGA}}{K_{\mathrm{DXP}, \mathrm{PGA}}+\mathrm{PGA}} \\
\frac{\mathrm{d}}{\mathrm{d} t} \mathrm{PGA} & =\frac{f_{\mathrm{PGA}}\left(A_{\mathrm{ps}} / 3+R_{d}\right)^{2}}{k_{\mathrm{MTP}}+A_{\mathrm{ps}} / 3+R_{d}} \\
& -V_{\mathrm{DXP}} \frac{\mathrm{GAP}}{K_{\mathrm{DXP}, \mathrm{GAP}}+\mathrm{GAP}} \frac{\mathrm{PGA}}{K_{\mathrm{DXP}, \mathrm{PGA}}+\mathrm{PGA}}
\end{aligned}
$$

$\frac{\mathrm{d}}{\mathrm{d} t} \mathrm{NADPH}=0$

$\frac{\mathrm{d}}{\mathrm{d} t} \mathrm{DXP}=V_{\mathrm{DXP}} \frac{\mathrm{GAP}}{K_{\mathrm{DXP}, \mathrm{GAP}}+\mathrm{GAP}} \frac{\mathrm{PGA}}{K_{\mathrm{DXP}, \mathrm{PGA}}+\mathrm{PGA}}$

$-V_{\mathrm{MEP}} \frac{\mathrm{NADPH} \text { DXP }}{K_{\mathrm{MEP}, D X P D X P}+K_{\mathrm{MEP}, \mathrm{NADPH}} \mathrm{NADPH}+\mathrm{NADPH} \mathrm{DXP}}$

$$
\begin{aligned}
\frac{\mathrm{d}}{\mathrm{d} t} \mathrm{MEP} & =V_{\mathrm{MEP}} \frac{\mathrm{NADPH} \text { DXP }}{K_{\mathrm{MEP}, \mathrm{DXP}} \mathrm{DXP}+K_{\mathrm{MEP}, \mathrm{NADPH}} \mathrm{NADPH}+\mathrm{NADPH} \text { DXP }} \\
& -V_{\mathrm{IDPs}} \frac{\mathrm{MEP}}{K_{\mathrm{IDPs}}+\mathrm{MEP}}
\end{aligned}
$$

$$
\frac{\mathrm{d}}{\mathrm{d} t} \mathrm{DMADP}=V_{\mathrm{IDPi}} \frac{\left(\mathrm{IDP}-\frac{\mathrm{DMAPD}}{K_{\mathrm{eq}, \mathrm{IDPi}}}\right)}{K_{\mathrm{IDPi}, \mathrm{IDP}}\left(1+\frac{\text { DMADP }}{K_{\text {IDPi,DMADP }}}\right)+\mathrm{IDP}}
$$$$
-V_{\mathrm{Is}} \frac{\text { DMADP }}{K_{\mathrm{Is}}+\text { DMADP }}
$$$$
-V_{\mathrm{GDPs}} \frac{\text { DMADP }}{K_{\mathrm{GDP}, \mathrm{DMADP}}+\mathrm{DMADP}} \frac{\mathrm{IDP}}{K_{\mathrm{GDP}, \text { IDP }}+\text { IDP }}
$$

$$
\frac{\mathrm{d}}{\mathrm{d} t} \mathrm{IDP}=V_{\mathrm{IDPs}} \frac{\mathrm{MEP}}{K_{\mathrm{IDPs}}+\mathrm{MEP}}
$$

$$
\begin{aligned}
& -V_{\mathrm{IDPi}} \frac{\left(\mathrm{IDP}-\frac{\mathrm{DMAPD}}{K_{\mathrm{eq}, \mathrm{IDP} i}}\right)}{K_{\mathrm{IDPi}, \mathrm{IDP}}\left(1+\frac{\mathrm{DMADP}}{K_{\mathrm{IDPi}, \mathrm{DMADP}}}\right)+\mathrm{IDP}} \\
& -V_{\mathrm{GDPs}} \frac{\mathrm{DMADP}}{K_{\mathrm{GDP}, \mathrm{DMADP}}+\mathrm{DMADP}} \frac{\mathrm{IDP}}{K_{\mathrm{GDP}, \mathrm{IDP}}+\mathrm{IDP}}
\end{aligned}
$$

$$
\begin{aligned}
\frac{\mathrm{d}}{\mathrm{d} t} \text { Isoprene } & =V_{\mathrm{IDPi}} \frac{\left(\mathrm{IDP}-\frac{\text { DMAPD }}{K_{\text {eq,IDPi }}}\right)}{K_{\mathrm{IDPi}, \mathrm{IDP}}\left(1+\frac{\mathrm{DMADP}}{K_{\mathrm{IDPi}, \mathrm{DMDP}}}\right)+\mathrm{IDP}} \\
& -d_{\text {Isoprene Isoprene }}
\end{aligned}
$$

$$
\begin{aligned}
\frac{\mathrm{d}}{\mathrm{d} t} \mathrm{GDP} & =V_{\mathrm{GDP}} \frac{\mathrm{DMADP}}{K_{\mathrm{GDP}, \mathrm{DMADP}}+\mathrm{DMADP}} \frac{\mathrm{IDP}}{K_{\mathrm{GDP}, \mathrm{IDP}}+\mathrm{IDP}} \\
& -V_{\mathrm{MTs}} \frac{\mathrm{GDP}}{K_{\mathrm{MTs}}+\mathrm{GDP}} \\
& -V_{\mathrm{GGDPs}}\left(\frac{\mathrm{GDP}}{K_{\mathrm{GGPDPs}}+\mathrm{GDP}}\right)^{2}
\end{aligned}
$$

$$
\frac{\mathrm{d}}{\mathrm{d} t} \text { Mono }=V_{\mathrm{MTs}} \frac{\mathrm{GDP}}{K_{\mathrm{MTs}}+\mathrm{GDP}}-d_{\mathrm{Mono}} \text { Mono }
$$

Note: The isoprene rate (Eq. 11) was not used in this study, as the Scots pines dominating the stand are monoterpenes emitters. 
Table A1. SIM-BIM photosynthesis model variables and constants with values.

\begin{tabular}{|c|c|c|c|}
\hline \multicolumn{4}{|c|}{ State variables } \\
\hline \multicolumn{2}{|l|}{$\begin{array}{l}g_{\mathrm{s}} \\
C_{\mathrm{i}} \\
A_{\mathrm{ps}}\end{array}$} & 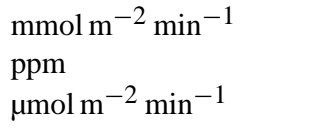 & $\begin{array}{l}\text { stomatal conductance } \\
\text { leaf internal } \mathrm{CO}_{2} \text { concentration } \\
\text { assimilation by photosynthesis }\end{array}$ \\
\hline \multicolumn{4}{|c|}{ Input variables } \\
\hline \multicolumn{2}{|l|}{$\begin{array}{l}I \\
\text { VPD }\end{array}$} & $\begin{array}{l}\mu \mathrm{mol} \text { photons } \mathrm{m}^{-2} \mathrm{~s}^{-1} \\
\mathrm{kPa}\end{array}$ & $\begin{array}{l}\text { PAR (photosynthetically active radiation) } \\
\text { vapour pressure deficit }\end{array}$ \\
\hline \multicolumn{4}{|c|}{ Constants } \\
\hline$k_{g}$ & 0.11 & $\min ^{-1}$ & stomatal conductance rate constant \\
\hline$G_{\max }$ & 61 & $\mathrm{mmol} \mathrm{m}^{-2}$ & max. stomatal opening \\
\hline$\alpha$ & 1.2 & (unitless) & slope of stomatal opening according to light \\
\hline$\beta$ & 133.6271 & $\mu \mathrm{mol}$ photons $\mathrm{m}^{-2} \mathrm{~s}^{-1}$ & curvature of stomatal opening according to light \\
\hline $\mathrm{VPD}_{0}$ & 3 & $\mathrm{kPa}$ & max. vapour pressure deficit \\
\hline$C_{\mathrm{a}}$ & 380 & ppm & air ambient $\mathrm{CO}_{2}$ concentration \\
\hline$\phi$ & 0.00185 & (unitless) & empirical scaling of $C_{\mathrm{i}}$ to the whole shoot ${ }^{\mathrm{a}}$ \\
\hline$v_{I}$ & 6.5 & $\mu \mathrm{mol} \mathrm{m}{ }^{-2} \min ^{-1}$ & max. speed of assimilation \\
\hline$k_{I}$ & 463.13 & $\mu \mathrm{mol} \mathrm{m}{ }^{-2}$ & kinetic constant for assimilation \\
\hline$\theta$ & 0.6 & $\min ^{-1}$ & use of assimilates ${ }^{b}$ \\
\hline$R_{d}$ & 0.2 & $\mu \mathrm{mol} \mathrm{m}{ }^{-2} \min ^{-1}$ & respiration \\
\hline
\end{tabular}

a The photosynthetical assimilation process takes place inside the chloroplasts, and, therefore, the process of using leaf internal $\mathrm{CO}_{2}$ concentration needs to be scaled to the extent to which it would take place on the gas-exchanging area of a coniferous shoot. $\mathrm{b}$ The Calvin cycle intermediates feed back to the carboxylation rate, and a fraction of the freshly assimilated C3 bodies are not instantly available (see Noe and Giersch, 2004). 
Table A2. SIM-BIM BVOC emission model variables and constants with values.

\begin{tabular}{|c|c|c|c|}
\hline \multicolumn{4}{|l|}{ State variables } \\
\hline GAP & & $\mathrm{mol} \mathrm{m}^{-2}$ & glyceraldehyde-3-phosphate \\
\hline PGA & & $\mathrm{mol} \mathrm{m}^{-2}$ & 3-phosphoglyceric acid \\
\hline NAPDH & & $\mathrm{mol} \mathrm{m}^{-2}$ & $\begin{array}{l}\text { reduced form of nicotinamide adenine dinucleotide } \\
\text { phosphate }\end{array}$ \\
\hline DXP & & $\mathrm{mol} \mathrm{m}^{-2}$ & 1-deoxy-D-xylulose 5-phosphate \\
\hline MEP & & $\mathrm{mol} \mathrm{m}^{-2}$ & $\begin{array}{l}\text { 2-C-methyl-D-erythritol 4-phosphate } \\
\text { (methylerythritol phosphate) }\end{array}$ \\
\hline IDP & & $\mathrm{mol} \mathrm{m}^{-2}$ & isopentenyl diphosphate \\
\hline DMADP & & $\mathrm{mol} \mathrm{m}^{-2}$ & dimethylallyl diphosphate \\
\hline Isoprene & & $\mathrm{mol} \mathrm{m}^{-2}$ & isoprene \\
\hline GDP & & $\mathrm{mol} \mathrm{m}^{-2}$ & geranyl diphosphate \\
\hline Mono & & $\mathrm{mol} \mathrm{m}^{-2}$ & monoterpenes \\
\hline \multicolumn{4}{|l|}{ Constants } \\
\hline$V_{Y}$ & & $\operatorname{mol~m}^{-2} \min ^{-1}$ & in general, max. rate of reaction producing $Y$ \\
\hline$K_{Y, X}$ & & $\mathrm{~mol} \mathrm{~m}^{-2}$ & $\begin{array}{l}\text { in general, Michaelis constant for reaction } X \rightarrow Y \\
\text { (concentration at which rate is half of max. rate) }\end{array}$ \\
\hline$V_{\mathrm{DXP}}$ & 1.9 & & \\
\hline$K_{\mathrm{DXP}, \mathrm{GAP}}$ & 6.16 & & \\
\hline$K_{\text {DXP,PGA }}$ & 6.16 & & \\
\hline$V_{\mathrm{MEP}}$ & 8.22 & & \\
\hline$K_{\text {MEP,DXP }}$ & 3.73333 & & \\
\hline$K_{\mathrm{MEP}, \mathrm{NADPH}}$ & 9.3333 & & \\
\hline$V_{\text {IDPs }}$ & 6.34 & & \\
\hline$K_{\mathrm{IDPs}}$ & 7.84 & & \\
\hline$V_{\mathrm{IDPi}}$ & 1.9467 & & \\
\hline$K_{\mathrm{IDPi}, \mathrm{IDP}}$ & 1.30667 & & \\
\hline$K_{\text {IDPi,DMADP }}$ & 1.30667 & & \\
\hline$K_{\text {eq,IDPi }}$ & 5.78667 & & \\
\hline$V_{\mathrm{GDPs}}$ & 81.57 & & \\
\hline$K_{\mathrm{GDP}, \mathrm{DMADP}}$ & 1.58667 & & \\
\hline$K_{\mathrm{GDP}, \mathrm{IDP}}$ & 1.04533 & & \\
\hline$V_{\mathrm{Is}}$ & 9.893 & & \\
\hline$K_{\mathrm{Is}}$ & 9.33333 & & \\
\hline$V_{\mathrm{MTs}}$ & 0.9893 & & \\
\hline$K_{\mathrm{MTs}}$ & 9.3333 & & \\
\hline$V_{\mathrm{GGDPs}}$ & 8.157 & & \\
\hline$K_{\mathrm{GGDPs}}$ & 1.58667 & & \\
\hline$k_{\mathrm{MTP}}$ & 80 & & \\
\hline$d_{\text {Isoprene }}$ & 0.0085 & $\min ^{-1}$ & isoprene diffusion rate \\
\hline$d_{\text {Mono }}$ & 0.0016 & $\min ^{-1}$ & monoterpenes diffusion rate \\
\hline$f_{\mathrm{PGA}}$ & 0.335 & (unitless) & fraction of PGA drainage for the assimilate \\
\hline
\end{tabular}


Acknowledgements. The financial support by the European Community's Seventh Framework Programme (FP7) in the project PEGASOS (grant agreement 265148), ERC Advanced Grant No. 227463 ATMNUCLE, Nordic Center of Excellence program (CRAICC - Cryosphere-Atmosphere Interactions in a Changing Arctic Climate), Academy of Finland Center of Excellence program (project No. 1118615), Helsinki University Centre for Environment (HENVI), the doctoral program ACCC (Atmospheric Composition and Climate Change), the EU Regional Development Foundation, Environmental Conservation and Environmental Technology R\&D Programme project BioAtmos (3.2.0802.11-0043), the EU Regional Development Foundation, Internationalization of Science Programme project INSMEARIN (10.1-6/13/1028) and the Estonian Science Foundation (Grant 8110) together with computational resources from CSC - IT Center for Science Ltd are all gratefully acknowledged.

Edited by: A. Massling

\section{References}

Aaltonen, H., Pumpanen, J., Pihlatie, M., Hakola, H., Hellén, H., Kulmala, L., Vesala, T., and Bäck, J.: Boreal pine forest floor biogenic volatile organic compound emissions peak in early summer and autumn, Agric. Forest Meteorol., 151, 682-691, 2011.

Aaltonen, H., Pumpanen, J., Hakola, H., Vesala, T., Rasmus, S., and Bäck, J.: Snowpack concentrations and estimated fluxes of volatile organic compounds in a boreal forest, Biogeosciences, 9, 2033-2044, doi:10.5194/bg-9-2033-2012, 2012.

Aaltonen, H., Aalto, J., Kolari, P., Pihlatie, M., Pumpanen, J., Kulmala, M., Nikinmaa, E., Vesala, T., and Bäck, J.: Continuous VOC flux measurements on boreal forest floor, Plant Soil, 369, 241-256, doi:10.1007/s11104-012-1553-4, 2013.

Arneth, A., Schurgers, G., Miller, P., and Hickler, T.: Effects of species composition, land surface cover, $\mathrm{CO}_{2}$ concentration and climate on isoprene emissions from European forests, Plant Biol., 10, 150-162, 2008.

Atkinson, R.: Gas-phase tropospheric chemistry of organic compounds, J. Phys. Chem. Ref. Data, Monograph, 2, 1-216, 1994.

Bäck, J., Aaltonen, H., Hellén, H., Kajos, M. K., Patokoski, J., Taipale, R., Pumpanen, J., and Heinonsalo, J.: Variable emissions of microbial volatile organic compounds (MVOCs) from root-associated fungi isolated from Scots pine, Atmos. Environ., 44, 3651-3659, 2010.

Bäck, J., Aalto, J., Henriksson, M., Hakola, H., He, Q., and Boy, M.: Chemodiversity of a Scots pine stand and implications for terpene air concentrations, Biogeosciences, 9, 689-702, doi:10.5194/bg-9-689-2012, 2012.

Bertin, N. and Staudt, M.: Effect of water stress on monoterpene emissions from young potted holm oak (Quercus ilex L.) trees, Oecologia, 107, 456-462, 1996.

Boy, M., Rannik, Ü., Lehtinen, K. E. J., Tarvainen, V., Hakola, H., and Kulmala, M.: Nucleation events in the continental PBL long term statistical analysis of aerosol relevant characteristics, J. Geophys. Res., 108, 4667-4679, 2003.

Boy, M., Sogachev, A., Lauros, J., Zhou, L., Guenther, A., and Smolander, S.: SOSA - a new model to simulate the concentrations of organic vapours and sulphuric acid inside the ABL -
Part 1: Model description and initial evaluation, Atmos. Chem. Phys., 11, 43-51, doi:10.5194/acp-11-43-2011, 2011.

Damian, V., Sandu, A., Damian, M., Potra, F., and Carmichael, G. R.: The kinetic pre-processor KPP - a software environment for solving chemical kinetics, Comput. Chem. Eng., 26, 1567-1579, 2002.

Dicke, M., Sabelis, M. W., Takabayashi, J., Bruin, J., and Posthumus, M. A.: Plant strategies of manipulating predator-prey interactions through allelochemicals: prospects for application in pest control, J. Chem. Ecol., 16, 3091-3118, 1990.

Fuentes, J. D. and Wang, D.: On the seasonality of isoprene emissions from a mixed temperate forest, Ecol. Appl., 9, 1118-1131, 1999.

Ghirardo, A., Koch, K., Taipale, R., Zimmer, I., Schnitzler, J.-P., and Rinne, J.: Determination of de novo and pool emissions of terpenes from four common boreal/alpine trees by ${ }^{13} \mathrm{CO}_{2}$ labelling and PTR-MS analysis, Plant Cell Environ., 33, 781-792, 2010.

Global Forest Resources Assessment 2000: Main Report, FAO Forestry Paper 140, FAO, Rome, 2001.

Greenberg, J., Asensio, D., Turnipseed, A., Huang, M., Guenther, A. B., Karl, T., and Gochis, D.: Contribution of leaf and needle litter to whole ecosystem BVOC fluxes, Atmos. Environ., 59, 302-311, 2012.

Grote, R.: Sensitivity of volatile monoterpene emission to changes in canopy structure: a model-based exercise with a process-based emission model, New Phytol., 173, 550-561, 2007.

Grote, R., Mayrhofer, S., Fischbach, R. J., Steinbrecher, R., Staudt, M., and Schnitzler, J.-P.: Process-based modelling of isoprenoid emissions from evergreen leaves of Quercus ilex (L.), Atmos. Environ., 40, S152-S165, 2006.

Grote, R., Keenan, T., Lavoir, A.-V., and Staudt, M.: Process-based simulation of seasonality and drought stress in monoterpene emission models, Biogeosciences, 7, 257-274, doi:10.5194/bg7-257-2010, 2010.

Guenther, A., Hewitt, C. N., Erickson, D., Fall, R., Geron, C., Graedel, T., Harley, P., Klinger, L., Lerdau, M., McKay, W. A., Pierce, T., Scholes, B., Steinbrecher, R., Tallamraju, R., Taylor, J., and Zimmerman, P.: A global model of natural volatile organic compound emissions, J. Geophys. Res., 100, 8873-8892, 1995.

Guenther, A., Baugh, B., Brasseur, G., Greenberg, J., Harley, P., Klinger, L., Serca, D., and Vierling, L.: Isoprene emission estimates and uncertainties for the Central African EXPRESSO study domain, J. Geophys. Res., 104, 30625-30639, 1999.

Guenther, A., Karl, T., Harley, P., Wiedinmyer, C., Palmer, P. I., and Geron, C.: Estimates of global terrestrial isoprene emissions using MEGAN (Model of Emissions of Gases and Aerosols from Nature), Atmos. Chem. Phys., 6, 3181-3210, doi:10.5194/acp-63181-2006, 2006.

Guenther, A. B., Jiang, X., Heald, C. L., Sakulyanontvittaya, T., Duhl, T., Emmons, L. K., and Wang, X.: The Model of Emissions of Gases and Aerosols from Nature version 2.1 (MEGAN2.1): an extended and updated framework for modeling biogenic emissions, Geosci. Model Dev., 5, 1471-1492, doi:10.5194/gmd-51471-2012, 2012.

Hakola, H.: Biogenic Volatile Organic Compound (VOC) Emissions From Boreal Deciduous Trees and Their Atmospheric Chemistry, Ph. D. thesis, University of Helsinki, 2002. 
Hakola, H., Rinne, J., and Laurila, T.: The hydrocarbon emission rates of tea-leafed willow (Salix phylicifolia), silver birch (Betula pendula) and European aspen (Populus tremula), Atmos. Environ., 32, 1825-1833, 1998.

Hakola, H., Tarvainen, V., Bäck, J., Ranta, H., Bonn, B., Rinne, J., and Kulmala, M.: Seasonal variation of mono- and sesquiterpene emission rates of Scots pine, Biogeosciences, 3, 93-101, doi:10.5194/bg-3-93-2006, 2006.

Hakola, H., Hellén, H., Tarvainen, V., Bäck, Patokoski, J., and Rinne, J.: Annual variations of atmospheric VOC concentrations in a boreal forest, Boreal Environ. Res., 14, 722-730, 2009.

Hari, P. and Kulmala, M.: Station for measuring ecosystematmosphere relations (SMEAR II), Boreal Environ. Res., 10, 315-322, 2005.

Hauff, K., Rössler, J., Hakola, H., and Steinbrecher, R.: Isoprenoid emission in the european boreal forests, in: Proceedings of EUROTRAC Symposium 98, edited by: Borrell, P. M. and Borrell, P., WIT Press, 1999.

Hayward, S., Muncey, R. J., James, A. E., Halsall, C. J., and Hewitt, C. N.: Monoterpene emissions from soil in a Sitka spruce forest, Atmos. Environ., 35, 4081-4087, 2001.

Helmig D., Daly R. W., Milford J. and Guenther A.: Seasonal trends of biogenic terpene emissions, Chemosphere, 93, 35-46, 2013.

Ilvesniemi, H., Levula, J., Ojansuu, R., Kolari, P., Kulmala, L., Pumpanen, J., Launiainen, S., Vesala, T., and Nikinmaa, E.: Long-term measurements of the carbon balance of a boreal Scots pine dominated forest ecosystem, Boreal Environ. Res., 14, 731753, 2009.

Janson, R.: Monoterpene emission of Scots pine and Norwegian spruce, J. Geophys. Res., 98, 2839-2850, 1993.

Kanakidou, M., Seinfeld, J. H., Pandis, S. N., Barnes, I., Dentener, F. J., Facchini, M. C., Van Dingenen, R., Ervens, B., Nenes, A., Nielsen, C. J., Swietlicki, E., Putaud, J. P., Balkanski, Y., Fuzzi, S., Horth, J., Moortgat, G. K., Winterhalter, R., Myhre, C. E. L., Tsigaridis, K., Vignati, E., Stephanou, E. G., and Wilson, J.: Organic aerosol and global climate modelling: a review, Atmos. Chem. Phys., 5, 1053-1123, doi:10.5194/acp5-1053-2005, 2005.

Kawamura, K. and Usukura, K.: Distributions of low molecular weight dicarboxylic acids in the North Pacific aerosol samples, J. Oceanogr., 49, 271-283, 1993.

Kesselmeier, J. and Staudt, M.: Biogenic volatile organic compounds (VOC): an overview on emission, physiology and ecology, J. Atmos. Chem., 33, 23-88, 1999.

Komenda, M. and Koppmann, R.: Monoterpene emissions from Scots pine (Pinus sylvestris): field studies of emission rate variabilities, J. Geophys. Res., 107, 4161, doi:10.1029/2001JD000691, 2002.

Kuhn, U., Rottenberger, S., Biesenthal, T., Wolf, A., Schebeske, G., Ciccioli, P., Brancaleoni, E., Frattoni, M., Tavares, T. M., and Kesselmeier, J.: Isoprene and monoterpene emissions of Amazonian tree species during the wet season: direct and indirect investigations on controlling environmental functions, J. Geophys. Res., 107, 8071-8084, 2002.

Kulmala, M., Hämeri, K., Aalto, P. P., Mäkelä, J. M., Pirjola, L., Nilsson, E. D., Buzorius, G., Rannik, Ü., Dal Maso, M., Seidl, W., Hoffman, T., Janson, R., Hansson, H.-C., Viisanen, Y., Laaksonen, A., and O'Dowd, C. D.: Overview of the interna- tional project on biogenic aerosol formation in the boreal forest (BIOFOR), Tellus B, 53, 324-343, 2001.

Kulmala, M., Suni, T., Lehtinen, K. E. J., Dal Maso, M., Boy, M., Reissell, A., Rannik, Ü., Aalto, P., Keronen, P., Hakola, H., Bäck, J., Hoffmann, T., Vesala, T., and Hari, P.: A new feedback mechanism linking forests, aerosols, and climate, Atmos. Chem. Phys., 4, 557-562, doi:10.5194/acp-4-557-2004, 2004.

Kulmala, M., Kontkanen, J., Junninen, H., Lehtipalo, K., Manninen, H. E., Nieminen, T., Petäjä, T., Sipilä, M., Schobesberger, S., Rantala, P., Franchin, A., Jokinen, T., Järvinen, E., Äijälä, M., Kangasluoma, J., Hakala, J., Aalto, P. P., Paasonen, P., Mikkilä, J., Vanhanen, J., Aalto, J., Hakola, H., Makkonen, U., Ruuskanen, T., Mauldin III, R. L., Duplissy, J., Vehkamäki, H., Bäck J., Kortelainen, A., Riipinen, I., Kurtén, T., Johnston, M. V., Smith, J. N., Ehn, M., Mentel, T. F., Lehtinen, K. E. J., Laaksonen, A., Kerminen, V.-M., and Worsnop, D. R.: Direct observations of atmospheric aerosol nucleation, Science, 339, 943-946, 2013.

Lamarque, J.-F., Bond, T. C., Eyring, V., Granier, C., Heil, A., Klimont, Z., Lee, D., Liousse, C., Mieville, A., Owen, B., Schultz, M. G., Shindell, D., Smith, S. J., Stehfest, E., Van Aardenne, J., Cooper, O. R., Kainuma, M., Mahowald, N., McConnell, J. R., Naik, V., Riahi, K., and van Vuuren, D. P.: Historical (1850-2000) gridded anthropogenic and biomass burning emissions of reactive gases and aerosols: methodology and application, Atmos. Chem. Phys., 10, 7017-7039, doi:10.5194/acp10-7017-2010, 2010.

Lappalainen, H. K., Sevanto, S., Bäck, J., Ruuskanen, T. M., Kolari, P., Taipale, R., Rinne, J., Kulmala, M., and Hari, P.: Daytime concentrations of biogenic volatile organic compounds in a boreal forest canopy and their relation to environmental and biological factors, Atmos. Chem. Phys., 9, 5447-5459, doi:10.5194/acp-9-5447-2009, 2009.

Lehning, A., Zimmer, W., Zimmer, I., and Schnitzler, J.-P.: Modelling of annual variations of oak (Quercus robur L.) isoprene synthase activity to predict isoprene emission rates, J. Geophys. Res., 106, 3157-3166, 2001.

Litvak, M. E. and Monson, R. K.: Patterns of induced and constitutive monoterpene production in conifer needles in relation to insect herbivory, Oecologia, 114, 531-540, 1998.

Loreto, F., Ciccioli, P., Brancaleoni, E., Frattoni, M., and Delfine, S.: Incomplete ${ }^{13} \mathrm{C}$ labelling of $\alpha$-pinene content of Quercus ilex leaves and appearance of unlabelled C in $\alpha$-pinene emission in the dark, Plant Cell Environ., 23, 229-234, 2000.

Loreto, F. and Schnitzler J.-P.: Abiotic stresses and induced BVOCs, Trends Plant Sci., 15, 154-166, 2010.

Mauldin III, R. L., Berndt, T., Sipilä, M., Paasonen, P., Petäjä, T., Kim, S., Kurten, T., Stratmann, F., Kerminen, V.-M., and Kulmala, M.: A new atmospherically relevant oxidant, Nature, 488, 193-196, 2012.

Mogensen, D., Smolander, S., Sogachev, A., Zhou, L., Sinha, V., Guenther, A., Williams, J., Nieminen, T., Kajos, M. K., Rinne, J., Kulmala, M., and Boy, M.: Modelling atmospheric OH-reactivity in a boreal forest ecosystem, Atmos. Chem. Phys., 11, 97099719, doi:10.5194/acp-11-9709-2011, 2011.

Monson, R. K., Grote, R., Niinemets, Ü., and Schnitzler, J.-P.: Modeling the isoprene emission rate from leaves, New Phytol., 195, 541-559, 2012. 
Müller, J.-F.: Geographical distribution and seasonal variation of surface emissions and deposition velocities of atmospheric trace gases, J. Geophys. Res., 97, 3787-3804, 1992.

Niinemets, Ü., Hauff, K., Bertin, N., Tenhunen, J. D., Steinbrecher, R., and Seufert, G.: Monoterpene emissions in relation to foliar photosynthetic and structural variables in Mediterranean evergreen Quercus species, New Phytol., 153, 243-256, 2002a.

Niinemets, Ü., Seufert, G., Steinbrecher, R., and Tenhunen, J. D.: A model coupling foliar monoterpene emissions to leaf photosynthetic characteristics in Mediterranean evergreen Quercus species, New Phytol., 153, 257-275, 2002b.

Niinemets, Ü.: Mild versus severe stress and BVOCs: thresholds, priming and consequences, Trends Plant Sci., 15, 145-153, 2010.

Noe, S. M. and Giersch, C.: A simple dynamic model of photosynthesis in oak leaves: coupling leaf conductance and photosynthetic carbon fixation by a variable intracellular $\mathrm{CO}_{2}$ pool, Funct. Plant Biol., 31, 1195-1204, 2004.

Nozière, B. and Esteve, W.: Organic reactions increasing the adsorption index of atmospheric sulfuric acid aerosols, Geophys. Res. Lett., 32, L03812, doi:10.1029/2004GL021942, 2005.

Peñuelas, J. and Staudt, M.: BVOCs and global change, Trends Plant Sci., 15, 133-144, 2010.

Pétron, G., Harley, P., Greenberg, J., and Guenther, A.: Seasonal temperature variations influence isoprene emission, Geophys. Res. Lett., 28, 1707-1710, 2001.

Piccot, S., Watson, J., and Jones, J.: A global inventory of volatile organic compound emissions from anthropogenic sources, J. Geophys. Res., 97, 9897-9912, 1992.

Pirinen, P., Simola, H., Aalto, J., Kaukoranta, J.-P., Karlsson, P., and Ruuhela, R.: Climatological Statistics of Finland 1981-2010, Finnish Meteorological Institute, Helsinki, Finland, 2012.

Rinne, J., Hakola, H., and Laurila, T.: Vertical fluxes of monoterpenes above a Scots pine stand in the boreal vegetation zone, Phys. Chem. Earth Pt. B, 24, 711-715, 1999.

Rinne, J., Bäck, J., and Hakola, H.: Biogenic volatile organic compound emissions from the Eurasian taiga: current knowledge and future directions, Boreal Environ. Res., 14, 807-826, 2009.

Robertson, G. W., Griffiths, D. W., Woodford, J. A. T., and Birch, A. N. E.: Changes in the chemical composition of volatiles released by the flowers and fruits of the red raspberry (Rubus idaeus) cultivar Glen Prosen, Phytochemistry, 38, 1175-1179, 1995.

Ruuskanen, T. M., Kolari, P., Bäck, J., Kulmala, M., Rinne, J., Hakola, H., Taipale, R., Raivonen, M., Altimir, N., and Hari, P.: On-line field measurements of monoterpene emissions from Scots pine by proton-transfer-reaction mass spectrometry, Boreal Environ. Res., 10, 553-567, 2005.

Sallas, L., Luomala, E. M.,Utriainen, J.,Kainulainen, P., and Holopainen, J. K.: Contrasting effects of elevated carbon dioxide concentration and temperature on Rubisco activity, chlorophyll fluorescence, needle ultrastructure and secondary metabolites in conifer seedlings, Tree Physiol., 23, 97-108, 2003

Sandu, A. and Sander, R.: Technical note: Simulating chemical systems in Fortran90 and Matlab with the Kinetic PreProcessor KPP-2.1, Atmos. Chem. Phys., 6, 187-195, doi:10.5194/acp-6187-2006, 2006.

Schuh, G., Heiden, A. C., Hoffmann, T., Kahl, J., Rockel, P., Rudolph, J., and Wildt, J.: Emissions of volatile organic com- pounds from sunflower and beech: dependence on temperature and light intensity, J. Atmos. Chem., 27, 291-318, 1997.

Schurgers, G., Arneth, A., Holzinger, R., and Goldstein, A. H.: Process-based modelling of biogenic monoterpene emissions combining production and release from storage, Atmos. Chem. Phys., 9, 3409-3423, doi:10.5194/acp-9-3409-2009, 2009.

Serca, D., Guenther, A., Klinger, L., Vierling, L., Harley, P., Druilhet, A., Greenberg, J., Baker, B., Baugh, W., Bouka-Biona, C., and Loemba-Ndembi, J.: EXPRESSO flux measurements at upland and lowland Congo tropical forest site, Tellus B, 53, 220234, 2001.

Sharkey, T. D. and Loreto, F.: Water stress, temperature, and light effects on the capacity for isoprene emission and photosynthesis of Kudzu leaves, Oecologia, 95, 328-333, 1993.

Sharkey, T. D., Singsaas, E. L., Lerdau, M. T., and Geron, C. D.: Weather effects on isoprene emission capacity and applications in emissions algorithms, Ecol. Appl., 9, 1132-1137, 1999.

Simpson, D., Winiwarter, W., Börjesson, G., Cinderby, S., Ferreiro, A., Guenther, A., Hewitt, C. N., Janson, R., Khalil, M. A. K., Owen, S., Pierce, T. E., Puxhaum, H., Shearer, M., Skiba, U., Steinbrecher, R., Tarrassón, L., and Öquist, M. G.: Inventorying emissions from nature in Europe, J. Geophys. Res., 104, 8113-8152, 1999.

Smiatek, G. and Steinbrecher, R.: Temporal and spatial variation of forest VOC emissions in Germany in the decade 1994-2003, Atmos. Environ., 40, S166-S177, 2006.

Staudt, M., Bertin, N., Frenzel, B., and Seufert, G.: Seasonal Variation in Amount and Composition of Monoterpenes Emitted by Young Pinus pinea Trees - Implications for Emission Modeling, Journal of Atmospheric Chemistry, 35, 77-99, 2000.

Steinbrecher, R., Hauff, K., Rössler, J., Dürr, M., and Seufert, G.: Monoterpene emission from soils in orange plantations of the Valencian citrus belt, Spain, Phys. Chem. Earth Pt. B, 24, 695698, 1999.

Stewart, H. E., Hewitt, C. N., Bunce, R. G. H., Steinbrecher, R., Smiatek, G., and Schoenemeyer, T.: A highly spatially and temporally resolved inventory for biogenic isoprene and monoterpene emissions: model description and application to Great Britain, J. Geophys. Res., 108, 4644, doi:10.1029/2002JD002694, 2003.

Taipale, R., Ruuskanen, T. M., Rinne, J., Kajos, M. K., Hakola, H., Pohja, T., and Kulmala, M.: Technical Note: Quantitative longterm measurements of VOC concentrations by PTR-MS - measurement, calibration, and volume mixing ratio calculation methods, Atmos. Chem. Phys., 8, 6681-6698, doi:10.5194/acp-86681-2008, 2008.

Taipale, R., Ruuskanen, T. M., and Rinne, J.: Lag time determination in DEC measurements with PTR-MS, Atmos. Meas. Tech., 3, 853-862, 2010, http://www.atmos-meas-tech.net/3/853/2010/.

Tani, A., Hayward, S., and Hewitt, C. N.: Measurement of monoterpenes and related compounds by proton transfer reaction-mass spectrometry (PTR-MS), Int. J. Mass Spectrom., 223-224, 561578, 2003.

Tarvainen, V., Hakola, H., Hellén, H., Bäck, J., Hari, P., and Kulmala, M.: Temperature and light dependence of the VOC emissions of Scots pine, Atmos. Chem. Phys., 5, 989-998, doi:10.5194/acp-5-989-2005, 2005. 
Tarvainen, V., Hakola, H., Rinne, J., Hellén, H., and Haapanala, S.: Towards a comprehensive emission inventory of terpenoids from boreal ecosystems, Tellus B, 59, 526-534, 2007.

Tooker, J. F., Crumrin, A. L., and Hanks, L. M.: Plant volatiles are behavioral cues for adult females of the gall wasp Antistrophus rufus, Chemoecology, 15, 85-88, 2005.

Trowbridge, A. M. and Stoy, P. C.: BVOC-mediated plant-herbivore interactions, In: Niinemets, Ü., and Monson, R. K. (eds), Biology, controls and models of tree volatile organic compound emissions, Springer, Berlin, 21-46, 2013.

Tsigaridis, K. and Kanakidou, M.: Importance of volatile organic compounds photochemistry over a forested area in central Greece, Atmos. Environ., 36, 3137-3146, 2002.
Vesala, T., Haataja, J., Aalto, P., Altimir, N., Buzorius, G., Garam, E., Hämeri, K., Ilvesniemi, H., Jokinen, V., Keronen, P., Lahti, T., Markkanen, T., Mäkelä, J. M., Nikinmaa, E., Palmroth, S., Palva, L., Pohja, T., Pumpanen, J., Rannik, Ü., Siivola, E., Ylitalo, H., Hari, P., and Kulmala, M.: Long-term field measurements of atmosphere-surface interactions in boreal forest combining forest ecology, micrometeorology, aerosol physics and atmospheric chemistry, Trends in Heat, Mass and Momentum Transfer, 4, 17-35, 1998.

Visser, J. H.: Host odor perception in phytophagous insects, Annu. Rev. Entomol., 31, 121-144, 1986.

Zimmer, W., Brüggemann, N., Emeis, S., Giersch, C., Lehning, A., Steinbrecher, R., and Schnitzler, J.-P.: Process-based modelling of the isoprene emission by oak leaves, Plant Cell Environ., 23, 585-595, 2000 . 